\title{
Natural Resources Assessment and Sea Level Rise Impact Using GIS and RS for North Alexandria and Kafr El Dawar District, Egypt
}

\author{
Ismail, M. ${ }^{1}$, Yehia, H. ${ }^{1}$, and Morsy, I. ${ }^{1}$
}

\begin{abstract}
Timely and reliable information on soils with respect to their nature, extent, spatial distribution is very crucial for optimal utilization of available natural resources on a sustained basis. The technological advances in the field of remote sensing, Global Positioning System (GPS) and Geographic Information System (GIS) have augmented the efficiency of soil survey. The management of resources on sustainable basis emphasis the overall development of the region without diminishing the environment. The integrated use of advanced computer technologies with database can be used to assist decision makers for future plans. The study area covers an area of 55872.098 ha, divided between Alexandria Governorate (8789 ha.) and Kafr El Dawar District, El Behira Governorate (47083.098 ha.). The agricultural land cover an area about 48142.124 ha, and the urban area occupy about 7729.97 ha. One hundred and four soil profiles were dug to characterize soil prosperities of the study area. One hundred forty-four water samples were collected from different irrigation, drainage network and water table to evaluate the quality of water in the study area. Impact of sea level rise for $\mathbf{5 0}$ $\mathrm{cm}$ and $100 \mathrm{~cm}$ on the natural resource was also investigated in the study area. The results shows that the study area consists of fourteen soil mapping units; the largest one was slightly saline, deep, high clay, calcareous which covered $24.8 \%$ of the total area and the smallest one was extremely saline, deep, clay, non calcareous which covered about $0.76 \%$ of the total area. The analysis of Digital Elevation Model (DEM) indicated that the elevations ranged between $<-20 \mathrm{~m}$ A.S.L. to $<60 \mathrm{~m}$ A.S.L. The main elevation from $-20 \mathrm{~m}$ A.S.L. to $-5 \mathrm{~m}$ A.S.L. covers an area about $29.71 \%$ of the total area. The analysis of sea level rise shows that $0.5 \mathrm{~m}$ increasing in sea level will submerged about $85.73 \%$ of the total area. If the sea level rise increase to $1 \mathrm{~m}, 90.73 \%$ of the study area will submerged. Most of the study area about 39096.52 ha. was classified as (C1), which indicated high capability with no limitations followed by $(\mathrm{C} 2 \mathrm{t}, \mathrm{Ca})$, which indicated moderately capability with soil texture and calcium carbonate content as limiting factors and covered an area about 7496.33 ha. followed by (C2, Ece), which indicated moderately capability with soil salinity as limiting factor.
\end{abstract}

Keywords: Soil survey, Geographic information system, Remote sensing, Land evaluation, Kafr el Dawar, North alexandria and Sea level rise.

\section{INTRODUCTION}

Egypt is a net food importer, including over half of its wheat needs. The increasing population and limited cultivated land, combined with land degradation and desertification pose significant challenges for production. Between 2010 and 2011 the total cultivated area in Egypt decreased by 1 percent, associated with encroachment on agricultural land (World Food Programme, 2013). Soil is a valuable non-renewable resource, which provides essential support to ecosystems and exists throughout the world in diverse behavior and properties. Over exploitation of resources to meet the basic amenities has not only depleted the finite land resources but also degraded their quality. The global demand for raw materials, industrial inputs and energy has been the main drivers of the depletion and degradation of resources (Cronin, 2009). Remote sensing techniques have been utilized in soil science for many years as a tool for soil surveyors, reducing the time and expense for sampling (Palacios-Orueta and Ustin, 1998; Ismail et al.,2011). Geographic information system (GIS) plays a major role in spatial decision-making. The collected information for the suitability analysis for crop production should present both opportunities and constraints for the decision maker (Ghafari et al., 2000). The ultimate aim of GIS is to provide support for spatial decisions making process (Foote and Lynch, 1996). Data layers in multi-criteria evaluation are handled in order to arrive at the suitability, which can be conveniently achieved using GIS. Remote sensing and GIS were used in many studies in Egypt for land resources mapping and management (Saleh et al., 2013 and Saleh and Belal, 2014). Dobos, et. al., (2000) stated that in recent years thematic mapping has undergone a revolution as the result of advances in geographic information science and remote sensing. For soil mapping archived data is often sufficient and this is available at low cost. Integration of Remote Sensing within a GIS database can decrease the cost, reduce the time and increase the detailed information gathered for soil survey. Particularly, the use of Digital Elevation Model (DEM) is important to derive landscape attributes that are utilized in land forms characterization. Beek, et. al.,(1997) suggested that RS data coupled with soil

\footnotetext{
${ }^{1}$ Soil, Water and Environment Res. Inst. (SWERI), Agricultural Research Center (ARC), Giza.

Received December 7, 2016, Accepted December 29, 2016
} 
survey information can be integrated in the geographical information system (GIS) to assess crop suitability for various soil and biophysical conditions in order to implement sustainable cropping systems in a watershed. The coastline is a vital region for Egypt, it contains tourism and considerable area of the agricultural land, and much of the industry and residential areas. The sea level rise affects the coastal population of six million people. Besides, the coastal region hosts several ecological systems of this region. The coastal ecosystem of the Nile Delta includes: (i) the Rosetta and Damietta Nile branch consisting of agricultural land, clusters of palm trees, sand dunes residues scattered in the middle of the area, wide sandy beaches, (ii) River Nile basin, (iii) different classes of Lakes and land cover. On the other hand, the urban environment is expressed in a hierarchy of urban clusters varying in size starting from a vast number of villages and farms and towns to large urban conglomeration resembling the main cities of Coastal Delta region (Ocean US, 2007). According to Nicholls and Leatherman (1995), a $1 \mathrm{~m}$ sea-level rise would affect 6 million people in Egypt, with $12 \%$ to $15 \%$ of agricultural land lost, 13 million in Bangladesh, with $16 \%$ of national rice production lost, and 72 million in China and "tens of thousands" of hectares of agricultural land. More than direct land loss due to seas rising, indirect factors are generally listed as the main difficulties associated with sea-level rise. These include erosion patterns and damage to coastal infrastructure, salinization of wells, sub-optimal functioning of the sewerage systems of coastal cities with resulting health impacts (WHO, 1996), loss of littoral ecosystems and loss of biotic resources. The objectives of this study were; 1) Characterization the land and water resources of the study area to help decision support system, 2) land evaluation using RS and GIS environments, to suggest suitable cropping patterns for the study area and 3) Study sea level rise impact on the study area to take the alternative solutions to mitigate this impact.

\section{MATERIALS AND METHODS}

\section{Study Area:}

\subsection{General Description}

The study area is located between $31^{\circ} 00^{\backslash}$ and $31^{\circ} 20$ $\mathrm{N}$ and $29^{\circ} 95^{\backslash}$ and $31^{\circ} 15^{\backslash} \mathrm{E}$ with total area of 55872.098 ha, divided between Alexandria Governorate (8789 ha.) and Kafr El Dawar District at El Behira Governorate (47083.098 ha.) as shown in map 1. The agricultural land cover about 48142.124 ha, and the urban area occupy about 7729.97 ha.

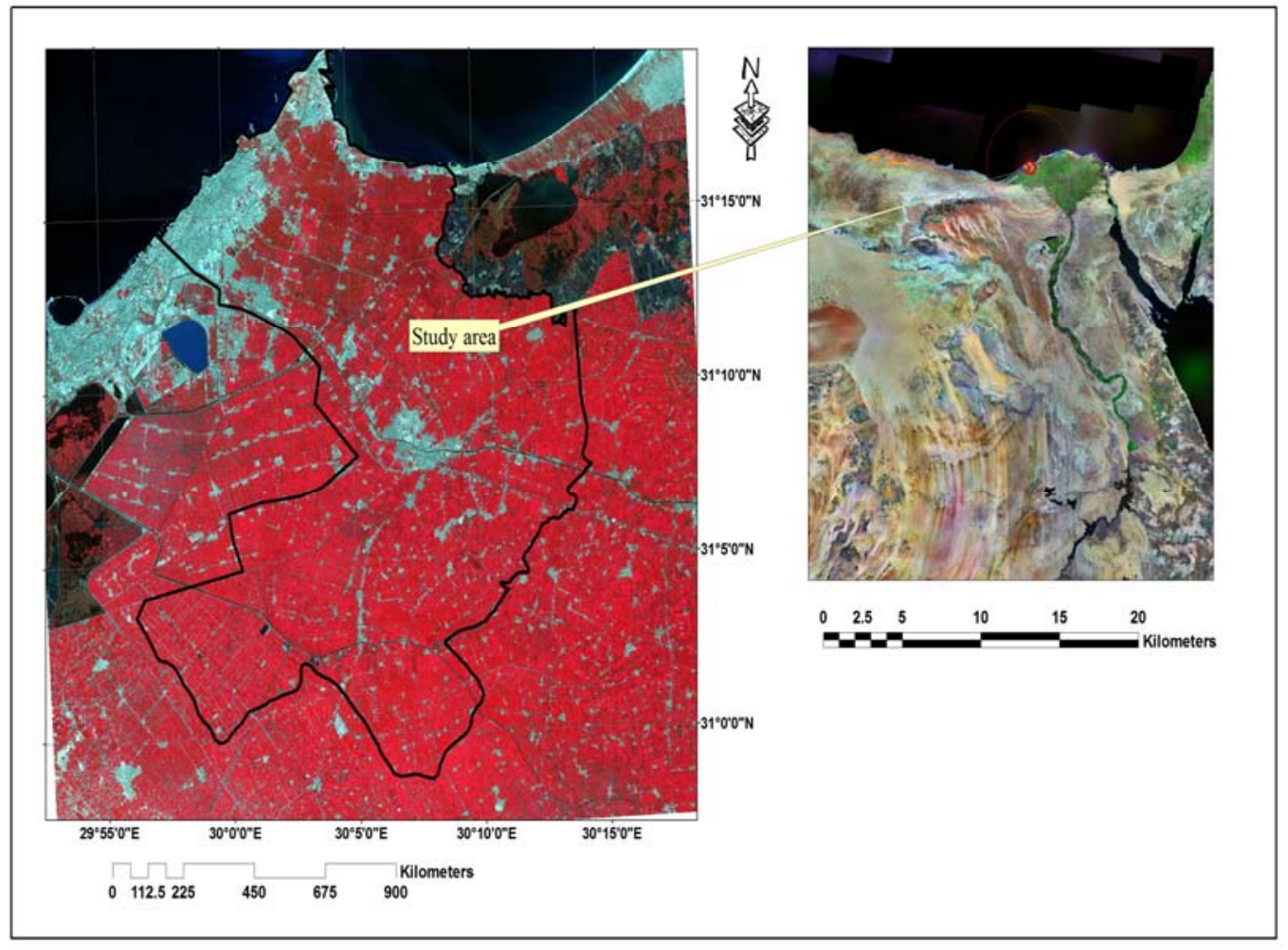

Map 1.Overlay of the study area on Landsat ETM +8 


\section{Field and Laboratory work:}

\subsection{Soil and water sampling design and analysis:}

One hundred and four soil profiles were dug to a depth of $60-150 \mathrm{~cm}$ with a random method depend on the surface characteristics of the study area with $500 \mathrm{~m}$ a minimum distance between each soil observation. The soil profiles were morphologically described in the field according to FAO (2010), and geo-referenced to UTM coordinate system map (2). The soil samples were collected from different horizons prepared and analyzed for chemical and physical characterization according to Page et al. (1982) and Klute, (1986). The fieldwork aimed to characterize the land units for the study area. Different water samples (64 irrigation water samples, 47 drainage water samples and 30 water table samples) were collected from each soil profile site as shown in map (3). Water samples were analyzed in order to characterize the water quality.

\section{Satellite Image:}

A window of Landsat ETM +8 (Enhanced Thematic Mapper) image acquired in May 2016 was selected to represent the study area as shown in map (1).

\subsection{Image Registration:}

Image registration is the first step to be carried out before proceeding to any further image processing. This step will assign coordinate systems to the image and linked it to its location on the ground. The ETM +8 image captured in May. 2016 was geometrically rectified to the digitized topographic maps using imageto-map procedure in ENVI 4.8 software (ENVI, 2008).

\subsection{Resolution Merge:}

This dialog enables to integrate imagery of different spatial resolutions (pixel size). Since higher resolution imagery is generally single band (ETM Panchromatic $15 \mathrm{~m}$ data), while multispectral imagery generally has the lower resolutions (ETM $30 \mathrm{~m}$ ), this technique is often used to produce high resolution, multispectral imagery. This improves the interpretability of the data by having high resolution information in color combinations. Resolution Merge offers three techniques: Multiplicative, Principal Components, and Brovey Transform (ERDAS 9.2, 2008).

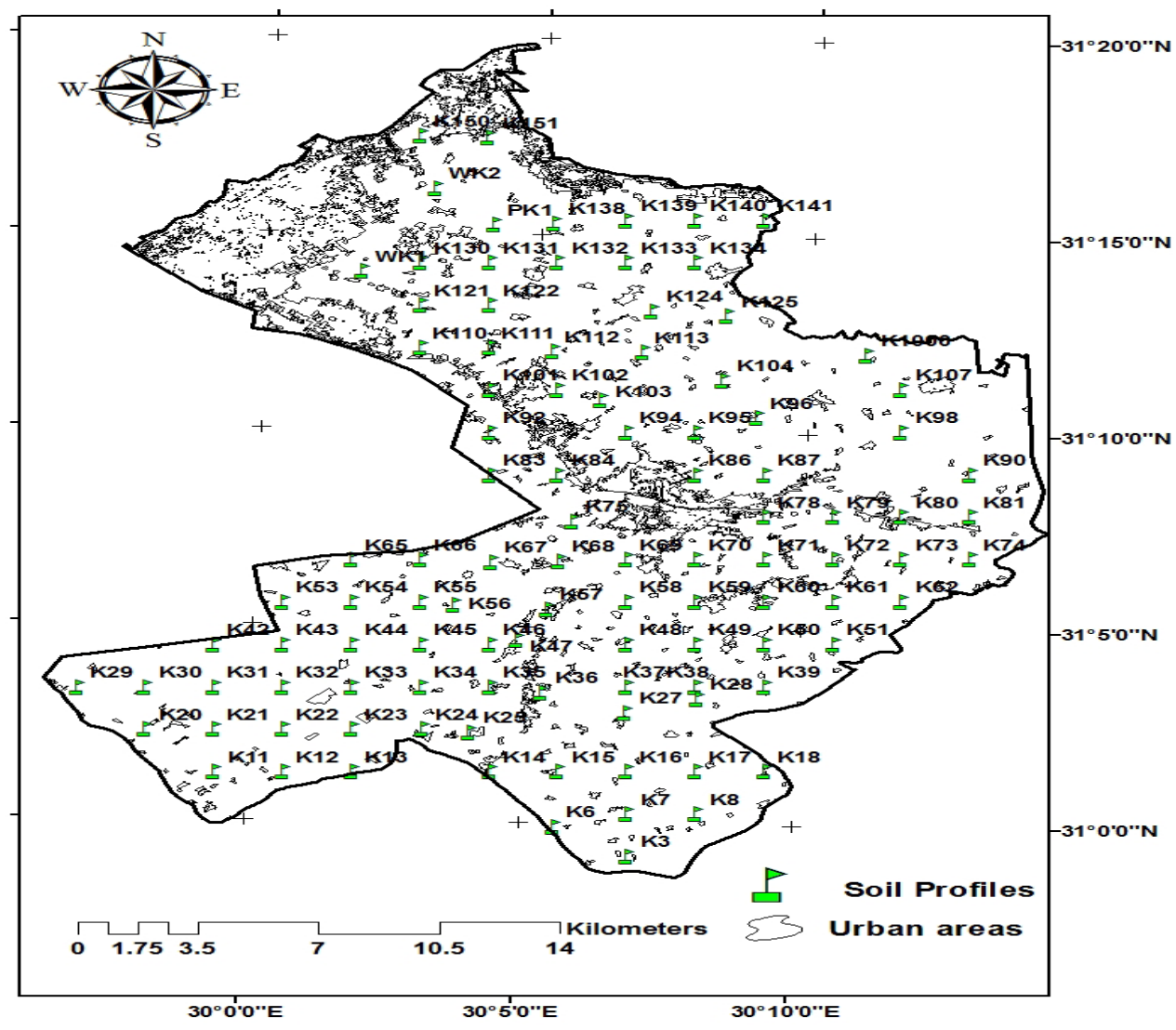

Map 2. Soil profiles distribution in the study area 


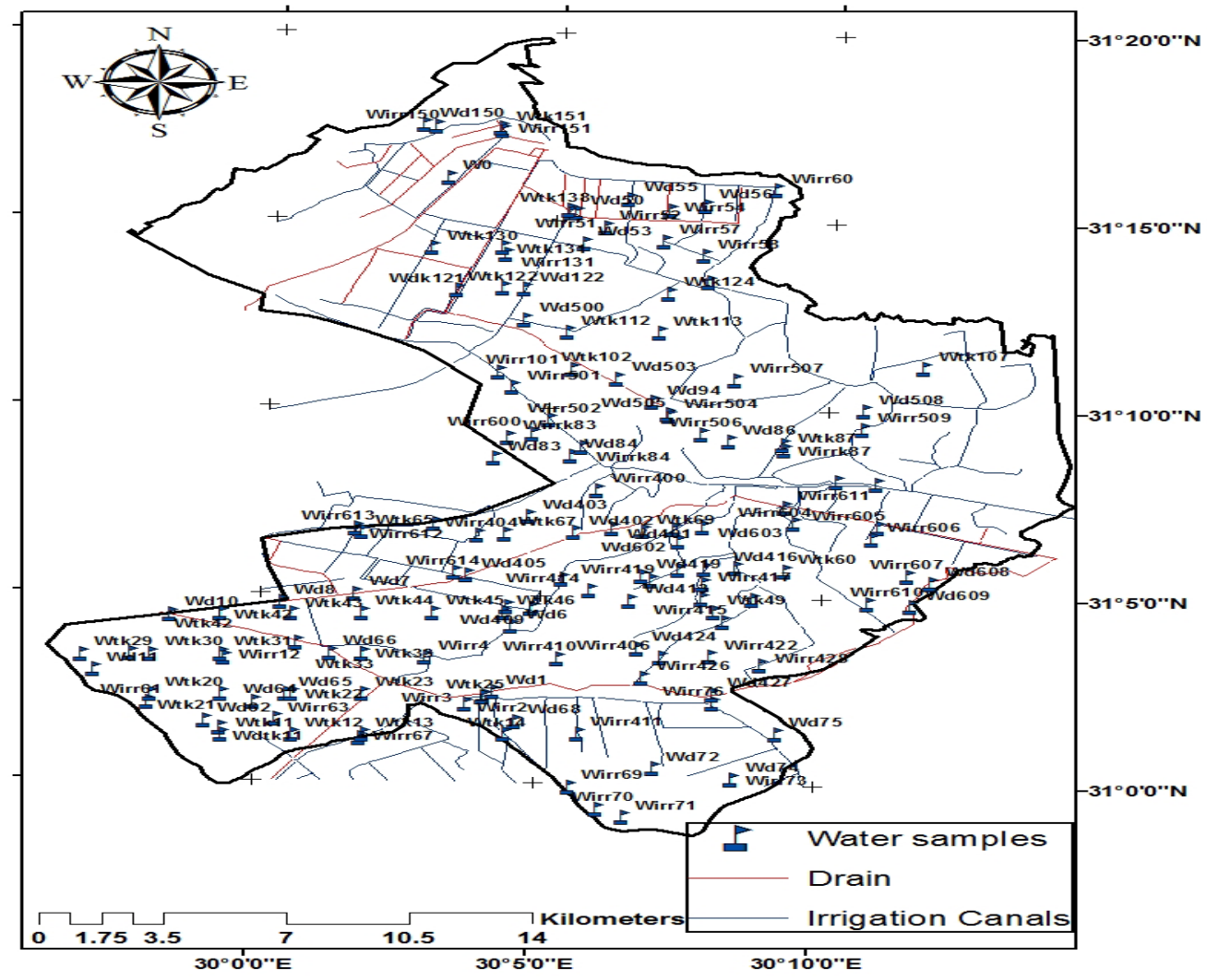

Map 3. Water samples location and irrigation-drainage network

4. Generation of DEM: The digitized contour lines and spot heights were utilized by Contour Gridder extension to generate the DEM within ArcGIS 10.3 environment.

5. Descriptive statistical parameters: Minimum, maximum, mean, standard deviation and coefficient of variance were calculated using SPSS software Ver. 12 (2003).

5.1. Building up Digital Georeference Database: Data input process is the operation of entering the spatial and non-spatial data into GIS using ArcGIS 10.3 software. Each soil observation was geo-referenced using the Global Position Systems (GPS) and digitized. The different soil attributes were coded, and new fields were added to the profile database file. Surface interpolate grid were done for soil salinity, Soil depth, $\mathrm{CaCO}_{3} \%$ using module Arc Scripts in ArcGIS 10.3 (ESRI, 2014).

6. Land evaluation: Land capability and suitability evaluation have been done using ALES-Arid according to Abd El-Kawy et al., 2010.

\section{RESULTS AND DISCUSSION}

1. Statistical characterization of soil profiles attributes: Table (1) indicates the statistical parameters of the soil profiles for the different soil horizons samples. The soil depth ranged from $60 \mathrm{~cm}$ to $150 \mathrm{~cm}$ with mean value about $113.85 \mathrm{~cm}$ and median about $120 \mathrm{~cm}$. The coefficient of variation of the soil depth was 0.12 which reflect high homogeneity in the study area. For the surface horizon the coefficient of variation shows that $\mathrm{pH}$, sand percentage, saturation percent and clay percentage were highly homogeneous $0.04,0.19$, 0.20 and 0.26 respectively. EC at the surface horizon ranged from 0.61 to $19.06 \mathrm{dS} / \mathrm{m}$ with median about $2.08 \mathrm{dS} / \mathrm{m}$. The less homogeneity properties were $\mathrm{EC}, \mathrm{dS} / \mathrm{m}, \mathrm{CaCO}_{3} \%$ and SAR; were $\mathrm{CV}, 0.93,0.79$ and 0.60 respectively. The same trend was observed at the subsurface horizons.

1.1. Spatial distribution of soil properties (attributes): Map (4) shows distribution of soil depth in the study area. The soil depth ranged from moderately deep $60-80 \mathrm{~cm}$ and represent an area about 217.50 ha. as a spot in the south part due to the high water table level, deep 80-120 cm which represents an area about 47437.40 ha. and distributed in all the study area and very deep $>120$ $\mathrm{cm}$ and represents an area about 553.07 ha. as located in the northern part of the study area. At the soil surface, it is clear that soil salinity is variable 
and ranged from $>2$ to $<16 \mathrm{dS} / \mathrm{m}$, where the dominant soil salinity was $2-4 \mathrm{dS} / \mathrm{m}$, it covered an area about of 23430.56 ha. and distributed in all the study area followed by $<2 \mathrm{dS} / \mathrm{m}$ class which covered an area about of 20174.63 ha. and mostly focused in the northern and southern west part of the study area as shown in map (5). For subsurface layer the dominant soil salinity class was $<2 \mathrm{dS} / \mathrm{m}$ which cover an area about 23580.77 ha. and found in the northern and middle part of the study area followed by $2-4 \mathrm{dS} / \mathrm{m}$ which covered an area about 18514.13 ha. and focused in the middle and southern part of the study area followed by $4-8$ $\mathrm{dS} / \mathrm{m}$ which occupy an area 5749.28 ha. appear in the southern edge of the study area as shown in map 6. Total calcium carbonate ranged from $<5 \%$ to $45 \%$ and classified into five classes. The dominant class was $10-20 \% 16515.18$ ha. and 15250.66 ha. for surface and subsurface layers mostly focused in the southern of the study area followed by $5-10 \%$ which covered an area about 12856.05 ha. and
13320.69 ha. respectively which distributed in the middle part of the study area as shown in maps 7 and 8. Spatial distribution of the surface clay content in the study area showed that the dominant clay content class ranged from $30-40 \%$ and covered an area about 25213.56 ha. and distributed in all the study area followed by $40-50 \%$ which occupy an area about 14690.89 ha. as shown in map 9. For subsurface layer the dominant clay content class was also $30-40 \%$ which covered an area about 20125.46 ha. followed by $40-50 \%$ which represent an area about 19671.03 ha. as shown in map 10.

1.2. Soil mapping units: The soil mapping units of the study area were extracted from the overlay of the main soil properties layers in the GIS environment such as soil depth, soil salinity, total calcium carbonate and soil texture. Fourteen soil units found in the study area as shown in map (11). Table (2) shows the percentage of each soil unit in the study area.

Table 1. Main statistical parameters of soil characteristics for the study area

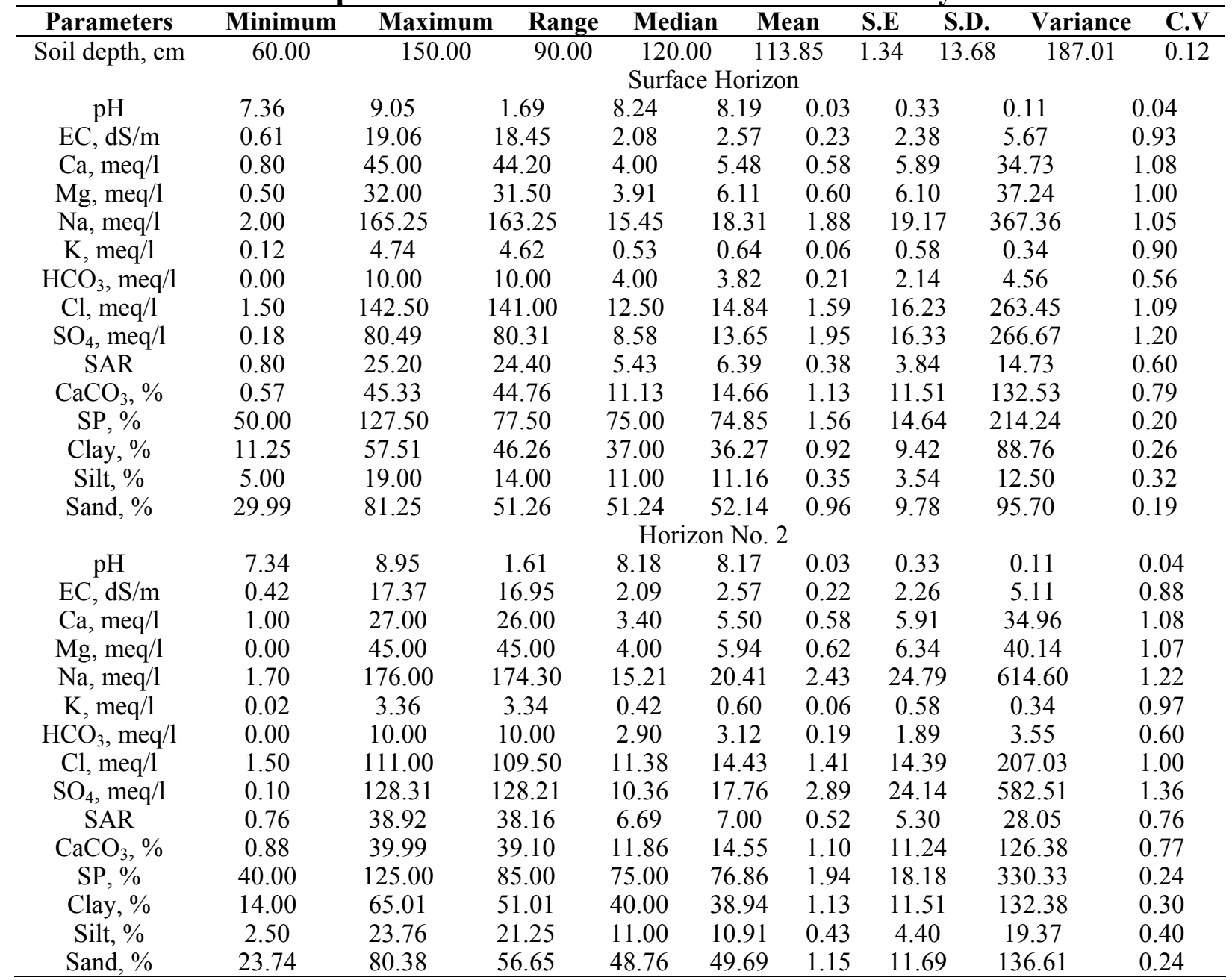


Table1. Cont.

\begin{tabular}{|c|c|c|c|c|c|c|c|c|c|}
\hline & \multicolumn{9}{|c|}{ Horizon No. 3} \\
\hline $\mathrm{pH}$ & 7.31 & 8.95 & 1.64 & 8.13 & 8.14 & 0.03 & 0.34 & 0.12 & 0.04 \\
\hline $\mathrm{EC}, \mathrm{dS} / \mathrm{m}$ & 0.50 & 13.56 & 13.06 & 2.05 & 2.68 & 0.20 & 2.04 & 4.16 & 0.76 \\
\hline $\mathrm{Ca}, \mathrm{meq} / \mathrm{l}$ & 1.00 & 28.00 & 27.00 & 3.50 & 4.71 & 0.46 & 4.70 & 22.07 & 1.00 \\
\hline $\mathrm{Mg}, \mathrm{meq} / \mathrm{l}$ & 0.00 & 35.00 & 35.00 & 4.20 & 6.26 & 0.58 & 5.92 & 35.08 & 0.95 \\
\hline $\mathrm{Na}, \mathrm{meq} / \mathrm{l}$ & 3.00 & 119.60 & 116.60 & 17.00 & 20.93 & 1.79 & 18.16 & 329.93 & 0.87 \\
\hline $\mathrm{K}, \mathrm{meq} / \mathrm{l}$ & 0.05 & 2.50 & 2.45 & 0.53 & 0.60 & 0.04 & 0.44 & 0.20 & 0.74 \\
\hline $\mathrm{HCO}_{3}, \mathrm{meq} / 1$ & 0.00 & 9.00 & 9.00 & 3.00 & 3.31 & 0.17 & 1.75 & 3.05 & 0.53 \\
\hline $\mathrm{Cl}, \mathrm{meq} / \mathrm{l}$ & 1.90 & 81.50 & 79.60 & 12.50 & 15.45 & 1.24 & 12.53 & 157.11 & 0.81 \\
\hline $\mathrm{SO}_{4}, \mathrm{meq} / 1$ & 0.25 & 96.60 & 96.35 & 10.22 & 16.92 & 2.36 & 19.60 & 384.00 & 1.16 \\
\hline SAR & 1.28 & 24.38 & 23.09 & 7.11 & 7.74 & 0.48 & 4.91 & 24.07 & 0.63 \\
\hline $\mathrm{CaCO}_{3}, \%$ & 0.00 & 43.99 & 43.99 & 12.47 & 14.79 & 1.12 & 11.35 & 128.91 & 0.77 \\
\hline SP, $\%$ & 35.00 & 185.00 & 150.00 & 75.00 & 78.08 & 2.68 & 24.96 & 623.15 & 0.32 \\
\hline Clay, \% & 11.00 & 68.76 & 57.76 & 36.26 & 37.34 & 1.30 & 13.16 & 173.20 & 0.35 \\
\hline Silt, $\%$ & 1.25 & 28.76 & 27.51 & 11.00 & 10.79 & 0.48 & 4.92 & 24.18 & 0.46 \\
\hline Sand, $\%$ & 21.23 & 83.75 & 62.51 & $\begin{array}{r}51.78 \\
\text { Hor }\end{array}$ & $\begin{array}{r}51.46 \\
\text { on No. }\end{array}$ & 1.35 & 13.69 & 187.50 & 0.27 \\
\hline $\mathrm{pH}$ & 7.26 & 8.85 & 1.59 & 8.11 & 8.11 & 0.03 & 0.31 & 0.09 & 0.04 \\
\hline $\mathrm{EC}, \mathrm{dS} / \mathrm{m}$ & 0.40 & 10.05 & 9.65 & 1.93 & 2.60 & 0.22 & 1.95 & 3.81 & 0.75 \\
\hline $\mathrm{Ca}, \mathrm{meq} / \mathrm{l}$ & 0.75 & 27.00 & 26.25 & 3.60 & 5.19 & 0.64 & 5.81 & 33.71 & 1.12 \\
\hline $\mathrm{Mg}, \mathrm{meq} / \mathrm{l}$ & 0.33 & 25.50 & 25.17 & 4.00 & 5.91 & 0.61 & 5.49 & 30.15 & 0.93 \\
\hline $\mathrm{Na}, \mathrm{meq} / \mathrm{l}$ & 2.00 & 90.80 & 88.80 & 13.69 & 20.69 & 2.12 & 19.16 & 367.19 & 0.93 \\
\hline $\mathrm{K}, \mathrm{meq} / \mathrm{l}$ & 0.05 & 1.70 & 1.65 & 0.42 & 0.51 & 0.04 & 0.34 & 0.12 & 0.68 \\
\hline $\mathrm{HCO}_{3}$, meq/l & 0.00 & 8.00 & 8.00 & 2.50 & 2.80 & 0.17 & 1.56 & 2.43 & 0.56 \\
\hline $\mathrm{Cl}, \mathrm{meq} / \mathrm{l}$ & 2.50 & 63.00 & 60.50 & 12.15 & 15.13 & 1.36 & 12.34 & 152.29 & 0.82 \\
\hline $\mathrm{SO}_{4}, \mathrm{meq} / 1$ & 0.07 & 115.37 & 115.30 & 8.70 & 17.32 & 3.11 & 23.26 & 540.82 & 1.34 \\
\hline SAR & 0.89 & 30.66 & 29.76 & 6.35 & 7.51 & 0.57 & 5.15 & 26.47 & 0.69 \\
\hline $\mathrm{CaCO}_{3}, \%$ & 0.72 & 35.00 & 34.28 & 11.85 & 13.37 & 1.18 & 10.68 & 114.13 & 0.80 \\
\hline SP, \% & 36.00 & 165.00 & 129.00 & 77.00 & 77.22 & 2.96 & 24.75 & 612.50 & 0.32 \\
\hline Clay, \% & 11.25 & 66.26 & 55.01 & 37.50 & 37.88 & 1.52 & 13.79 & 190.22 & 0.36 \\
\hline Silt, \% & 1.25 & 28.76 & 27.51 & 11.00 & 11.32 & 0.62 & 5.57 & 30.97 & 0.49 \\
\hline Sand, $\%$ & 18.73 & 87.50 & 68.76 & 50.13 & 50.33 & 1.63 & 14.78 & 218.34 & 0.29 \\
\hline
\end{tabular}

Table 2. The area and percentage of soil units

\begin{tabular}{lc}
\hline Soil unit & Area, \% \\
\hline Non Saline & 12.67 \\
\hline Deep, Clay, Calcareous & 21.21 \\
Deep, Clay, n. Calcareous & 1.91 \\
Deep, h. Clay, Calcareous & 11.03 \\
Deep, h. Clay, n. Calcareous & 0.80 \\
Mod. Deep, Clay, n. Calcareous & 2.28 \\
Slightly Saline & 2.87 \\
Deep, Clay, Calcareous & 24.80 \\
Deep, Clay, n. Calcareous & 13.28 \\
Deep, h. Clay, Calcareous & 0.88 \\
Deep, h. Clay, n. Calcareous & 3.19 \\
Saline & 1.45 \\
Deep, h. Clay, Calcareous & \\
Deep, h. Clay, n. Calcareous & 2.87 \\
Mod. Deep, h. Clay, n. Calcareous & \\
Strongly Saline & 0.76 \\
Deep, Clay, n. Calcareous & \\
Extremely Saline & \\
Deep, Clay, n. Calacreous & \\
\hline
\end{tabular}




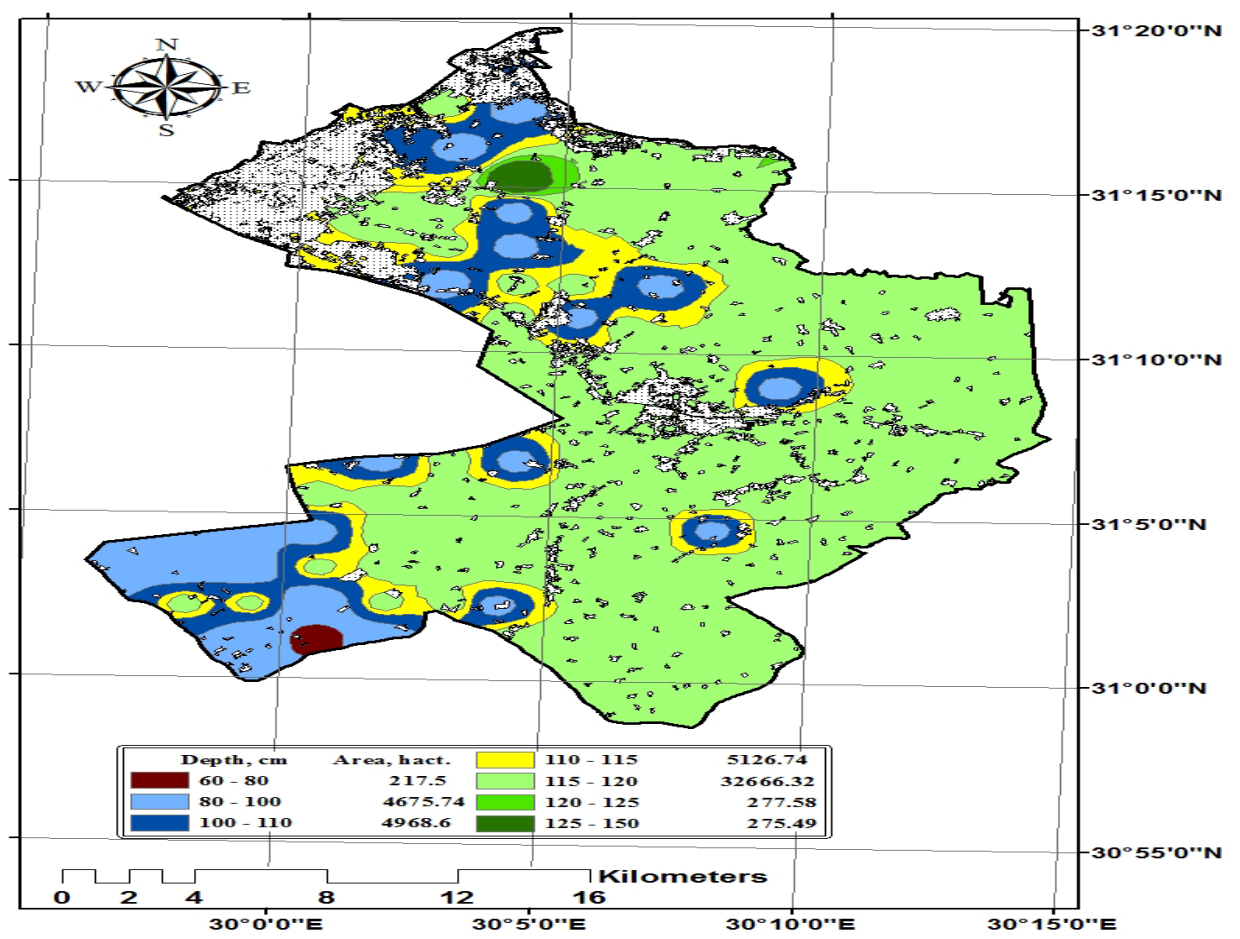

Map 4. Soil profile depth distribution of the study area

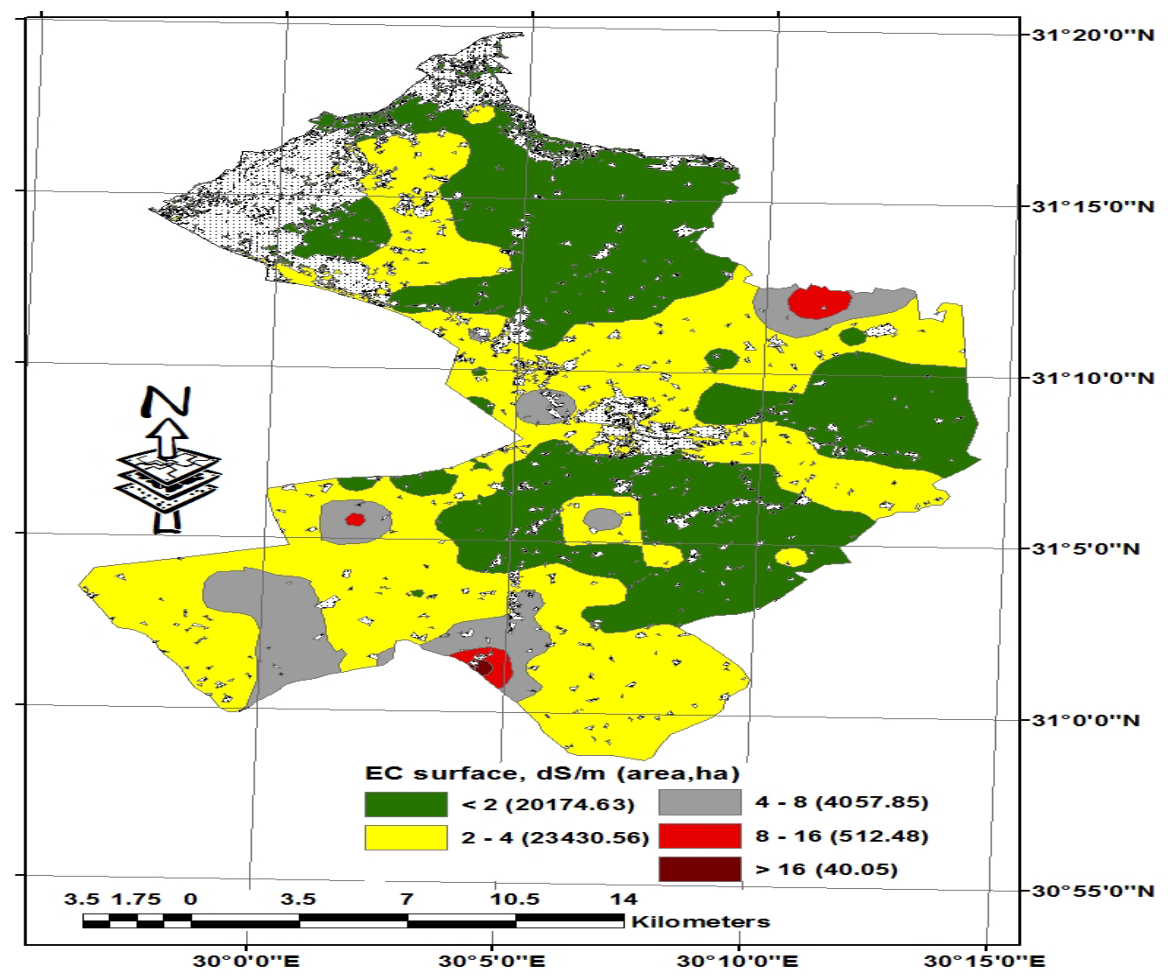

Map 5. Surface soil salinity distribution in the study area 


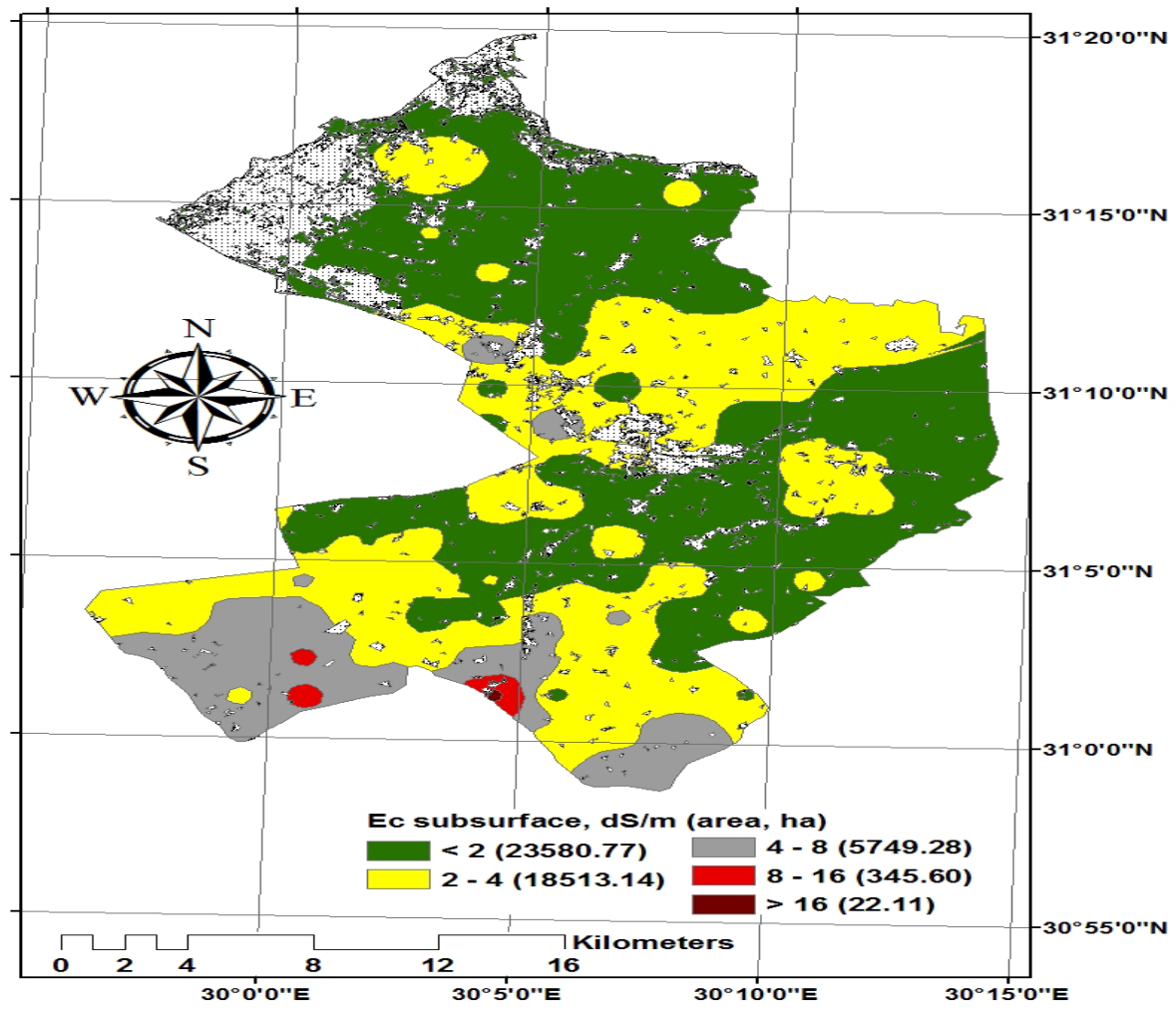

Map 6. Subsurface soil salinity distribution in the study area

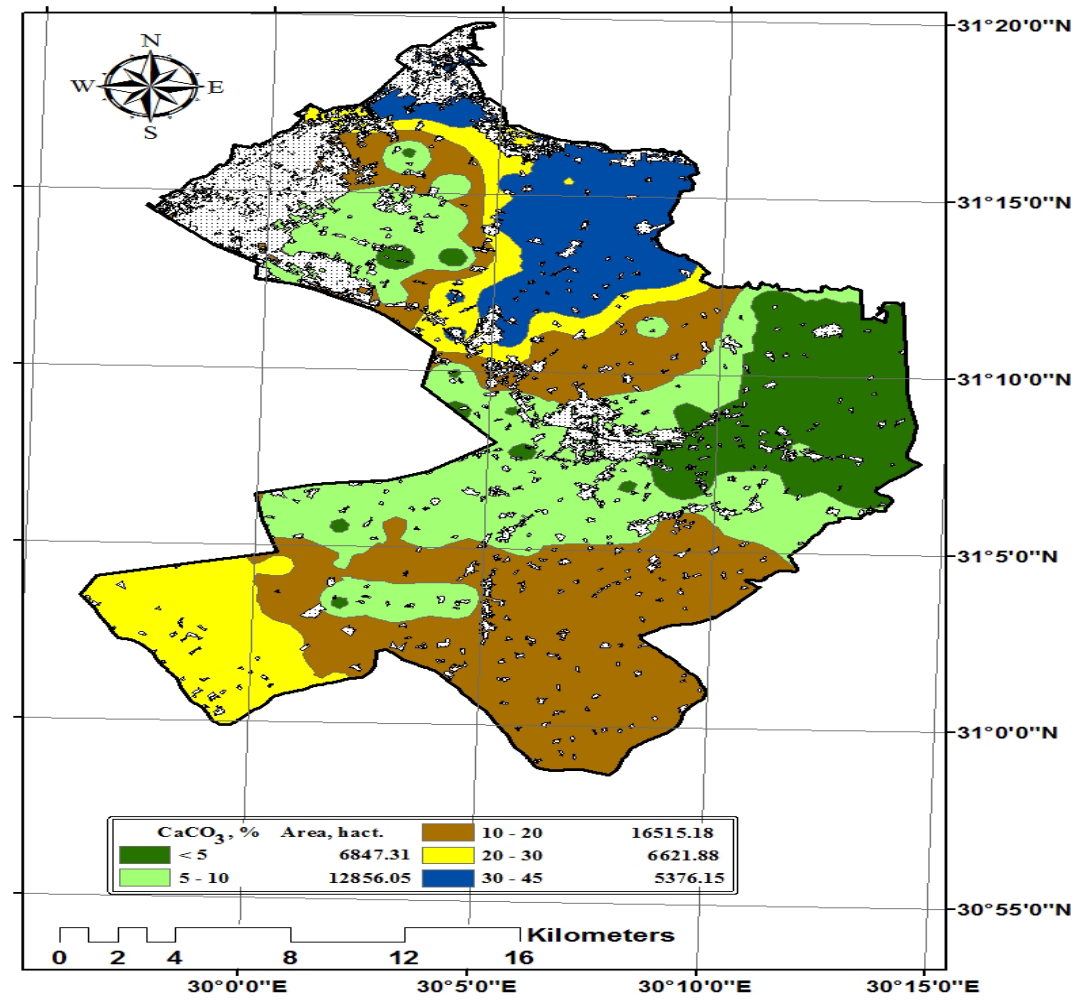

Map 7. Surface soil calcium carbonate distribution in the study area 


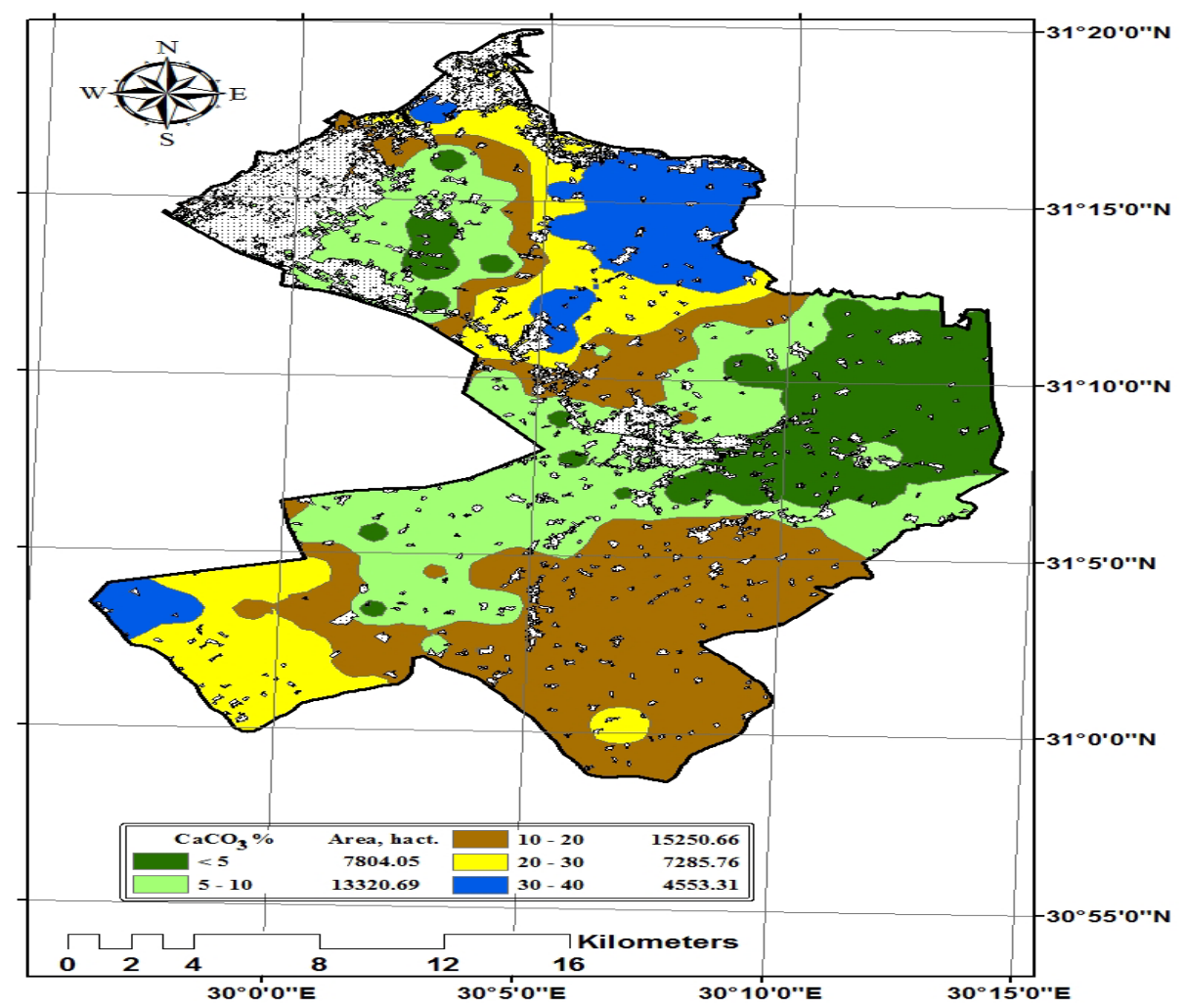

Map 8. Subsurface soil calcium carbonate distribution in the study area

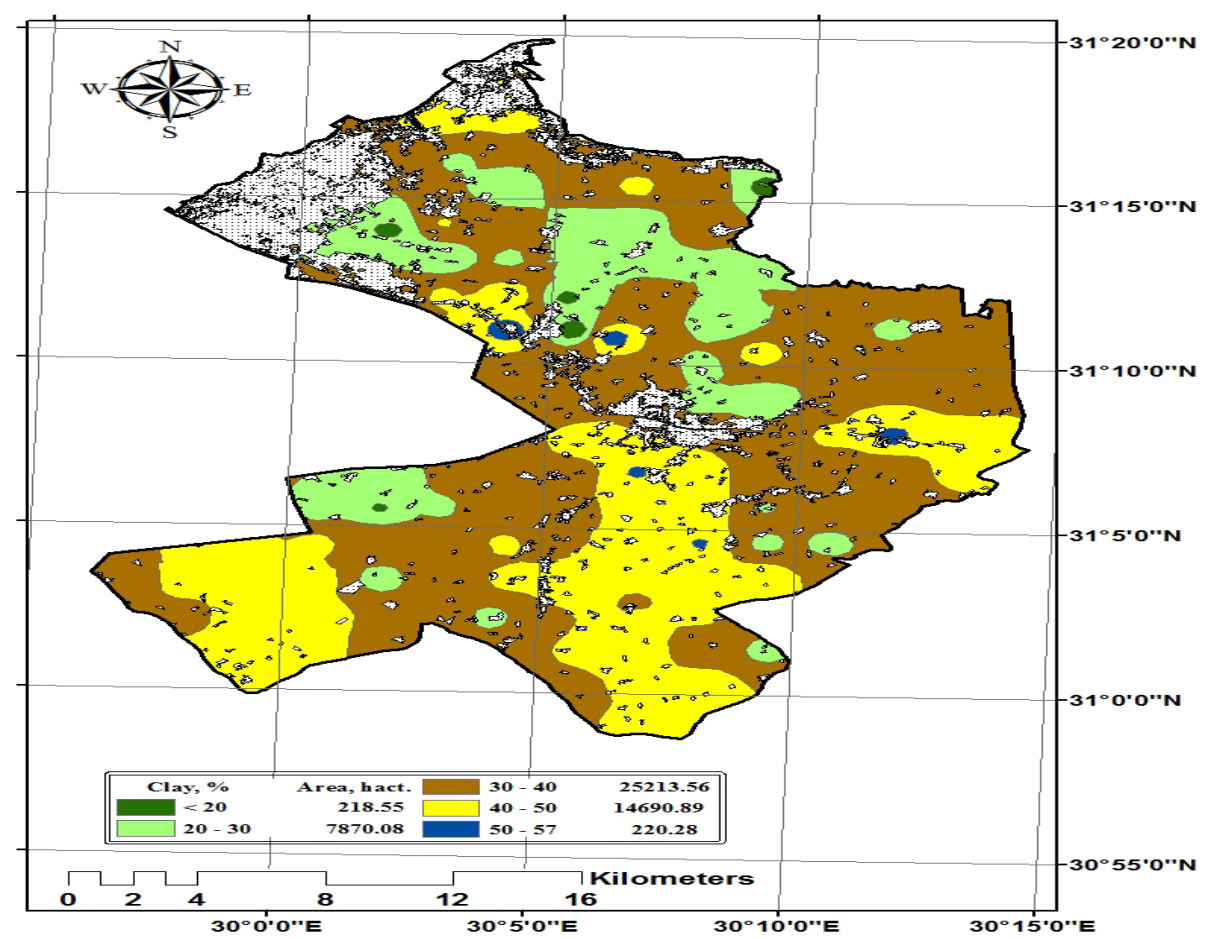

Map 9. Surface clay content distribution of the study area 


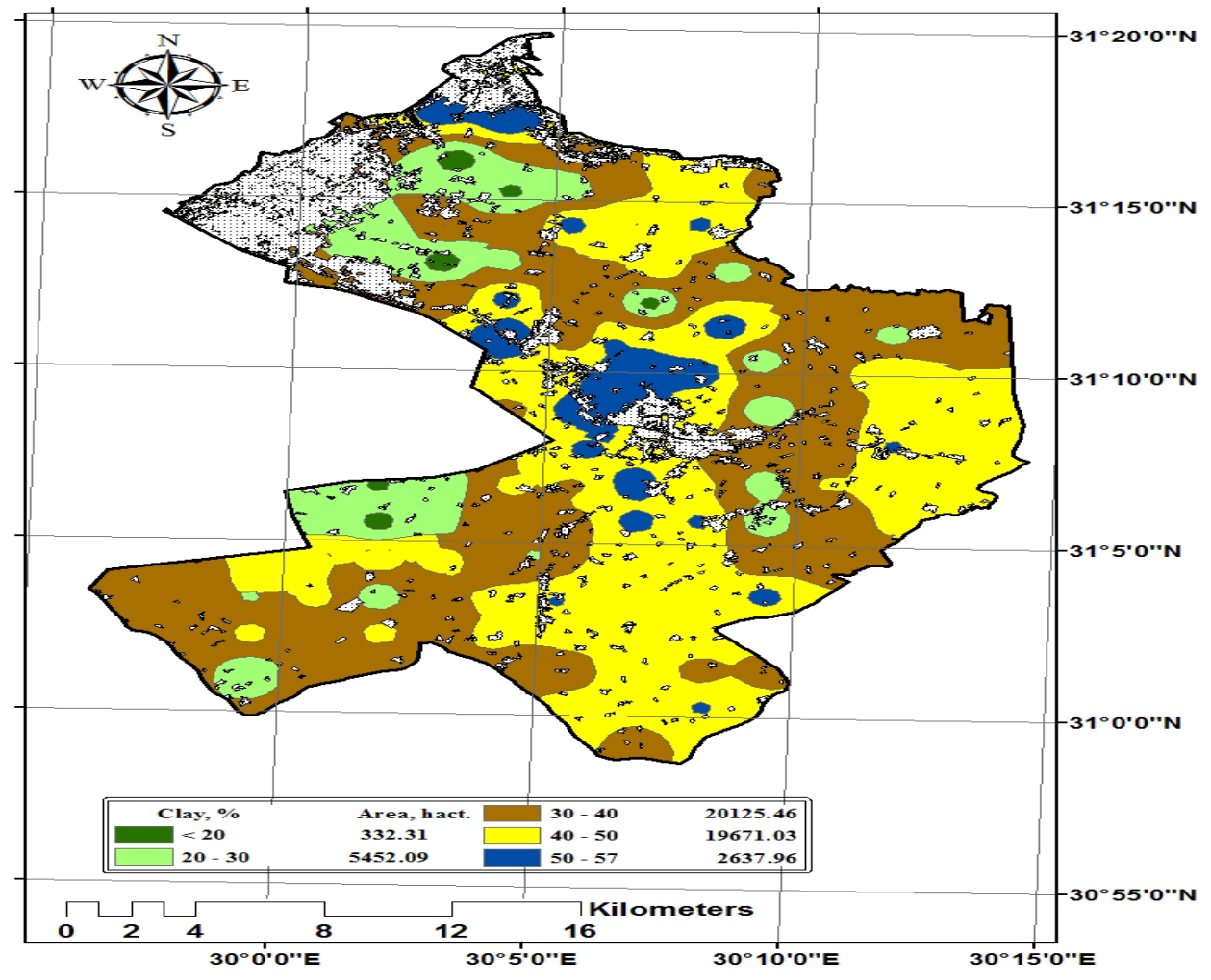

Map 10. Subsurface clay content distribution in the study area

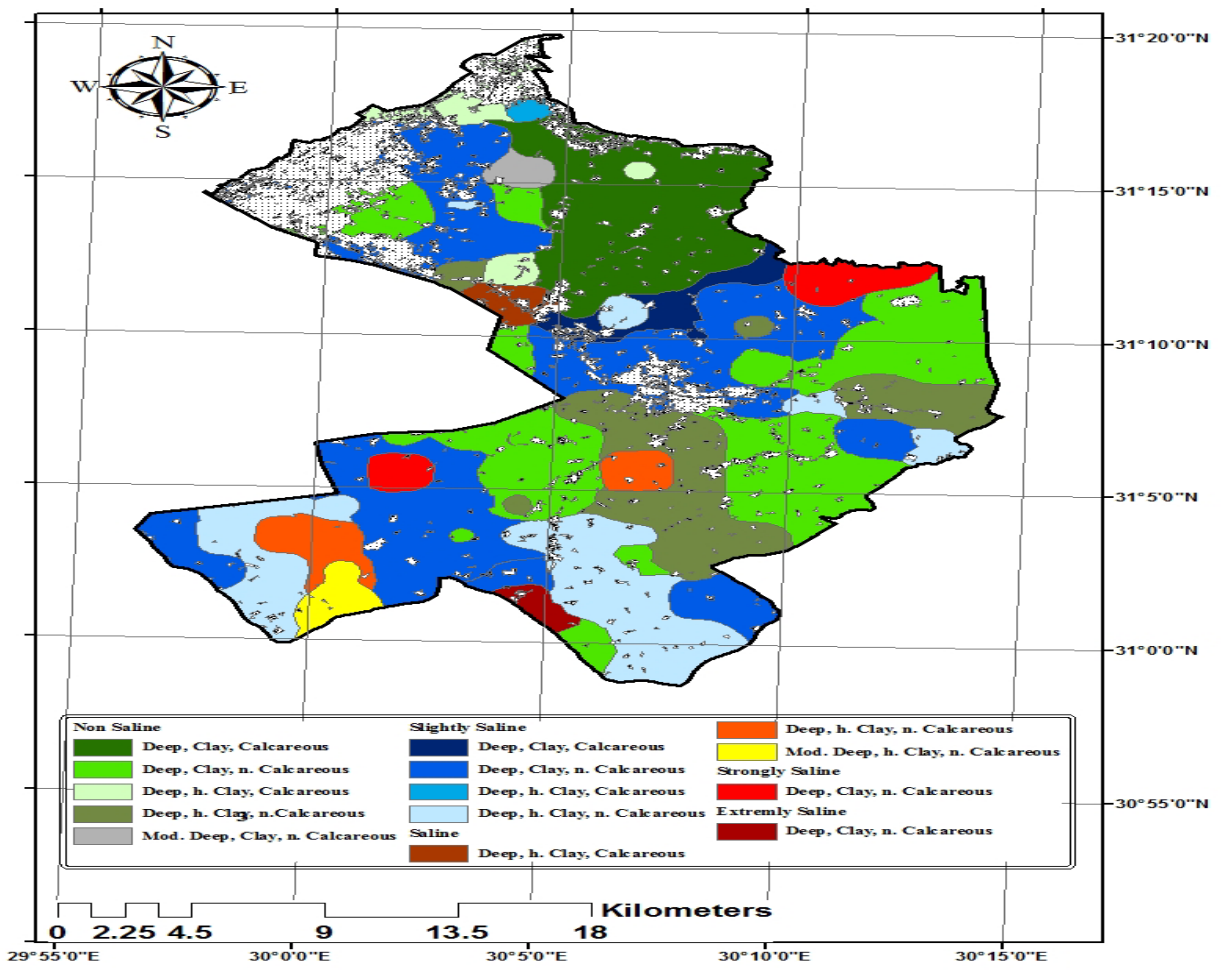

Map 11. Soil mapping units distribution in the study area 


\section{Statistical characterization of water samples:}

Table (3) indicates the statistical parameters of the water samples for the study area. Sixty four irrigation water samples, fourty seven drainage water samples and thirty water table samples. For irrigation water samples its clear that the lower value of water salinity was found in irrigation water samples and it ranged from 0.56 to $2.63 \mathrm{dS} / \mathrm{m}$. Salinity in water table samples ranged from 0.74 to $12.54 \mathrm{dS} / \mathrm{m}$ which the highest values was found in drainage water samples which ranged from 0.58 to $112.30 \mathrm{dS} / \mathrm{m}$. The result's show that the Residual Sodium Carbonate (RSC) values are suitable for irrigation and ranged from -4.00 to $0.8,-10$ to 1.00 and -33.00 to -1.00 for irrigation, water table and drainage water samples, respectively. For irrigation water samples the highest homogeneous parameteries were $\mathrm{SO}_{4}, \mathrm{Cl}, \mathrm{Na}$ and EC since C.V. values were 1.03, 0.84, 0.75 , and 0.50 respectively. For water table samples the highest homogeneous parameteries were $\mathrm{CO}_{3}, \mathrm{Cl}, \mathrm{Na}$, $\mathrm{Mg}$ and $\mathrm{EC}$ as $\mathrm{C}$. V. values were 2.19, 2.02, 2.08, 2.02 and 1.17 , respectively. Data show also that the highest homogeneous parameteries for drainage water samples were $\mathrm{CO}_{3}, \mathrm{EC}, \mathrm{K}$ and $\mathrm{Cl}$ where $\mathrm{C}$. V. values were 3.87 , $2.30,1.29$ and 0.87 respectively.

Map (12) shows the distribution of irrigation water salinity in the study area which ranged from $<2$ to 8 $\mathrm{dS} / \mathrm{m}$. It is clear that the lower value of irrigation water salinity was found in the western part of the study area which irrigated from the Nile water. EC gradually increased in the south and north part which closed to Idko Lake. Map (13) shows the distribution of drainage water salinity in the study area which ranged from $<2$ to $>12 \mathrm{dS} / \mathrm{m}$. It is found that the lower value of drainage water salinity was observed in the middle part of the study area which may be due to the soil salinity, clay content distribution and high elevation in this part of the study area and increase in some spots closed to Idko lake and the south part. The distribution of water table salinity in the study area which ranged from $<2$ to $>19 \mathrm{dS} / \mathrm{m}$ has the same trend as drainage water salinity (map 14).

Table 3. Main statistical parameters of water samples characteristics for the study area

\begin{tabular}{|c|c|c|c|}
\hline Parameters & $\mathrm{EC}, \mathrm{dS} / \mathrm{m}$ & SAR & RSC \\
\hline \multicolumn{4}{|c|}{ Irrigation Water Samples (64 samples) } \\
\hline Minimum & 0.45 & 1.53 & -31.59 \\
\hline Maximum & 8.60 & 15.42 & 9.11 \\
\hline Range & 8.15 & 13.88 & 40.69 \\
\hline Mean & 1.89 & 5.24 & -4.02 \\
\hline Median & 0.93 & 2.91 & -2.15 \\
\hline St. D. & 1.91 & 4.16 & 5.61 \\
\hline Variance & 3.66 & 17.31 & 31.43 \\
\hline C. V. & 1.01 & 0.79 & -1.39 \\
\hline \multicolumn{4}{|c|}{ Drainage Water Samples (47 samples) } \\
\hline Minimum & 0.55 & 2.03 & -50.85 \\
\hline Maximum & 12.20 & 16.88 & 16.88 \\
\hline Range & 11.65 & 14.85 & 14.85 \\
\hline Mean & 3.05 & 7.45 & 7.45 \\
\hline Median & 2.20 & 6.54 & 6.54 \\
\hline St. D. & 2.58 & 4.39 & 4.39 \\
\hline Variance & 6.66 & 19.25 & 19.25 \\
\hline C. V. & 0.85 & 0.59 & 0.059 \\
\hline \multicolumn{4}{|c|}{ Water Table Samples (30 samples) } \\
\hline Minimum & 0.75 & 2.52 & -42.61 \\
\hline Maximum & 19.20 & 41.74 & -1.66 \\
\hline Range & 18.45 & 39.22 & 40.95 \\
\hline Mean & 7.52 & 15.70 & -17.13 \\
\hline Median & 6.45 & 14.21 & -14.52 \\
\hline St. D. & 4.57 & 9.08 & 10.68 \\
\hline Variance & 20.88 & 82.49 & 113.97 \\
\hline C. V. & 0.61 & 0.58 & -0.62 \\
\hline
\end{tabular}




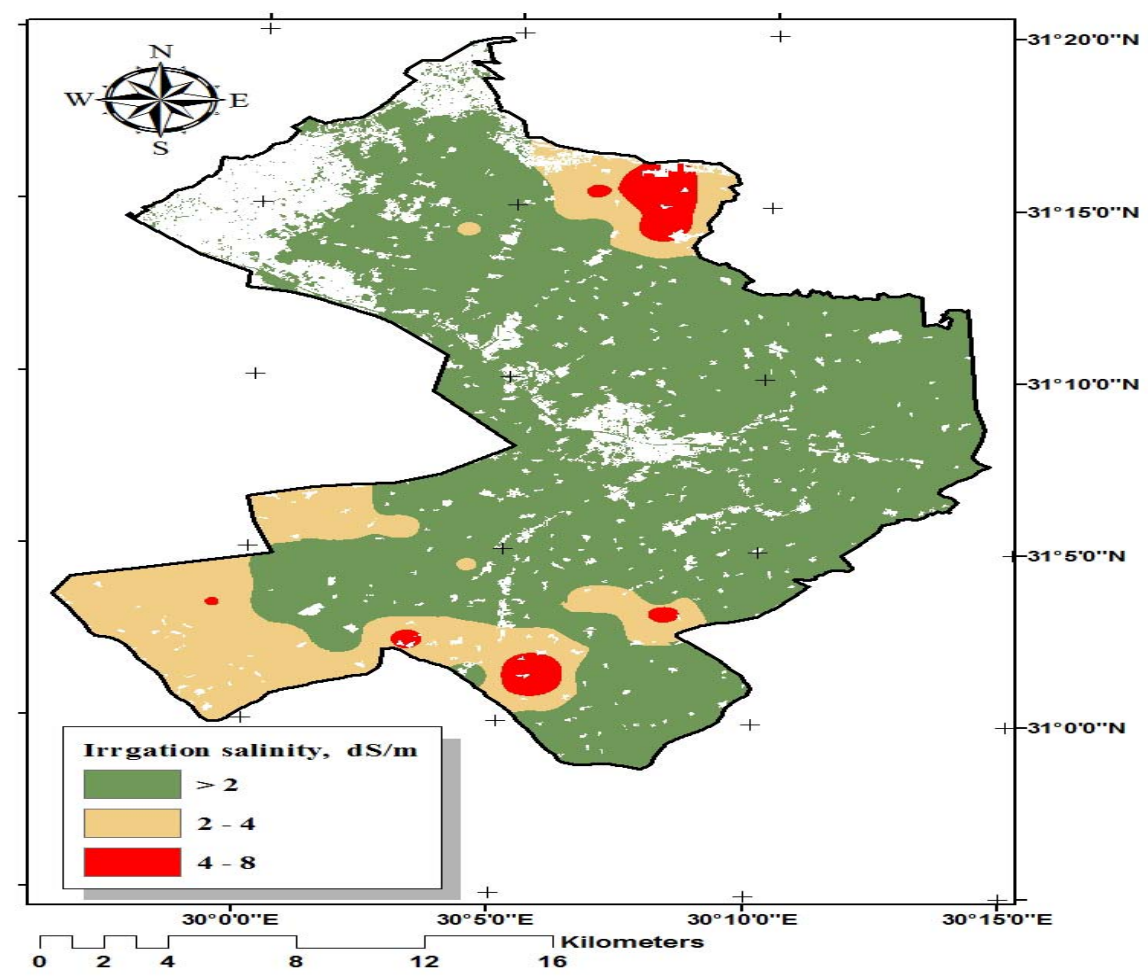

Map 12. Irrigation water salinity distribution in the study area

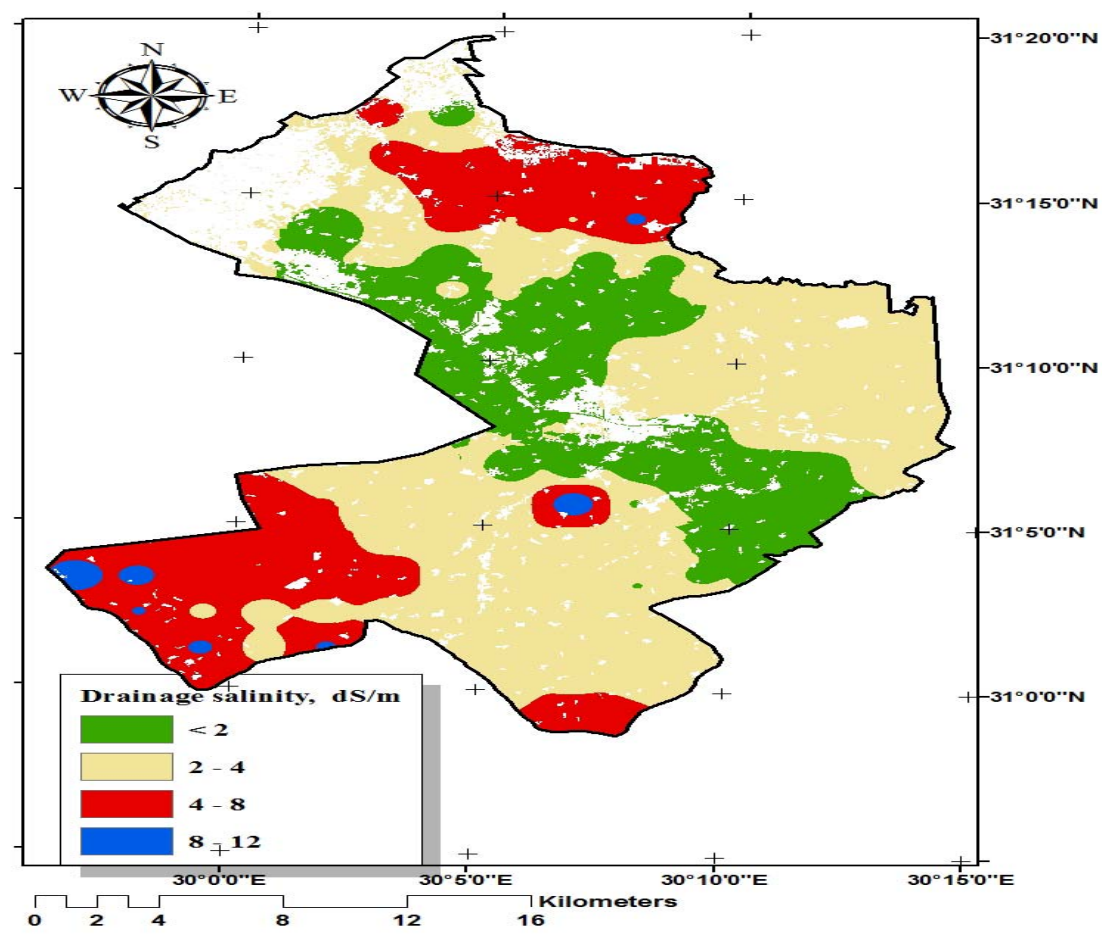

Map 13. Drainage water salinity distribution in the study area 


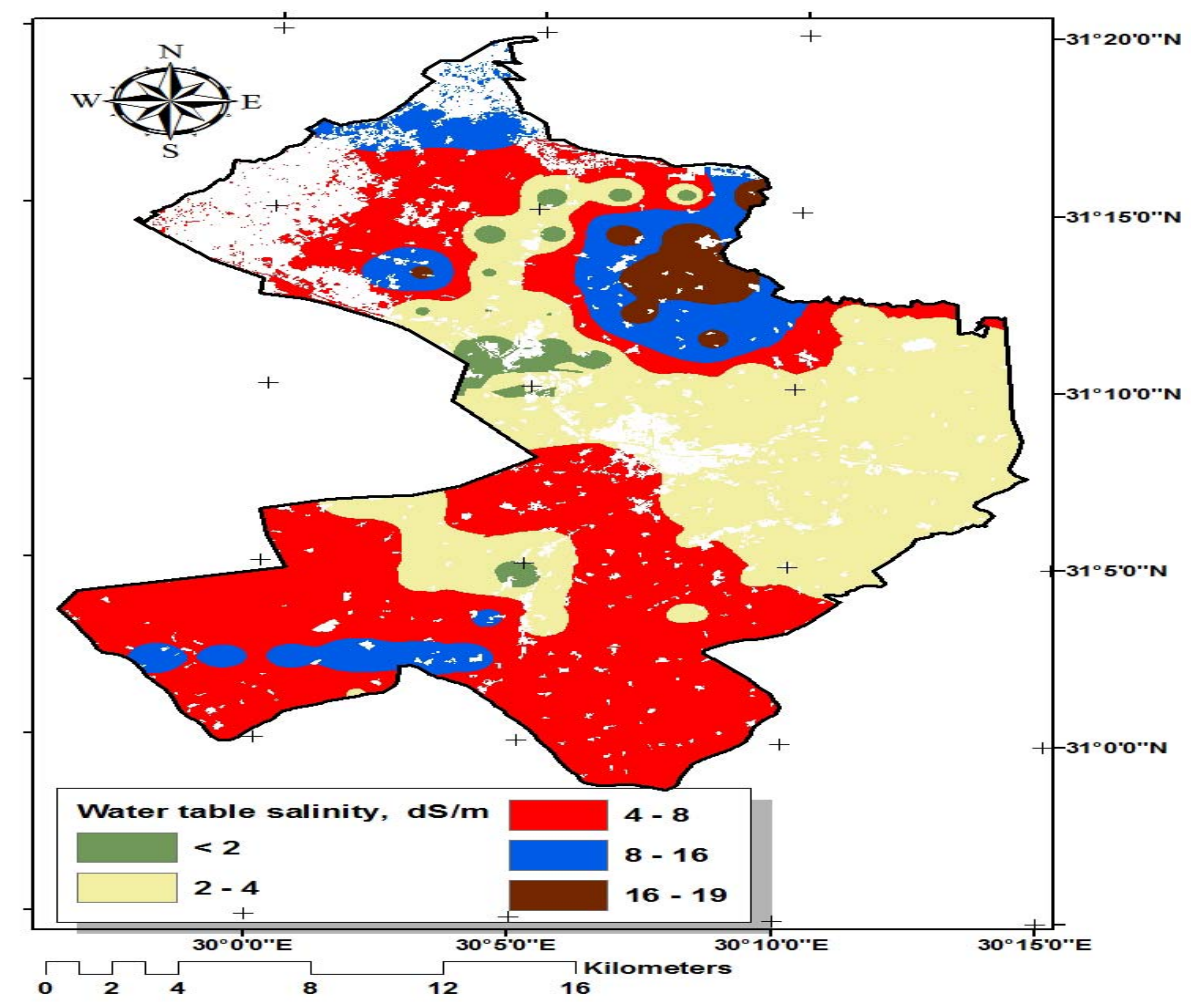

Map 14. Water table salinity distribution in the study area

\section{Terrain components:}

a) Digital Elevation Model (DEM): The analysis of DEM indicated that the elevations ranged between $<$ $-20 \mathrm{~m}$ A.S.L. to $<60 \mathrm{~m}$ A.S.L. The main elevation is from $-20 \mathrm{~m}$ A.S.L. to $-5 \mathrm{~m}$ A.S.L. and covers an area about $29.71 \%$ of the total area distributed in all the study area followed by the elevation $-5 \mathrm{~m} \mathrm{A.S.L.} \mathrm{to}$ $0 \mathrm{~m}$ A.S.L. which compress an area about $26.52 \%$ of the study area and mostly focused in the western and northern parts of the study area as shown in map (15).

b) Slope: It is clear that the dominant slope class is $0-$ $2 \%$ which covering $63.62 \%$ of the total study area and mostly focused in the middle part of the study area followed by slope class $2-4 \%$ that covered an area about $33.48 \%$ as shown in Table (4).

Table 4. Slope classes and area percentage of the study area

\begin{tabular}{lc}
\hline Slope class & Area, $\%$ \\
\hline $0-2$ & 63.62 \\
$2-4$ & 33.48 \\
$4-6$ & 2.79 \\
$6-10$ & 0.11 \\
\hline
\end{tabular}

c) Aspect: Table (5) indicates the percentage of each aspect class in the study area. It is noticeable that the south facing directions ( $\mathrm{S}, \mathrm{SE}$, and $\mathrm{SW}$ ) is the dominant aspect representing $37.44 \%$ of the total area followed by the north facing directions $(\mathrm{N}, \mathrm{NE}$, and NW) compress an area about $37.11 \%$ of the total area.

Table 5. Direction and area percentage of aspect of the study area

\begin{tabular}{lclc}
\hline Direction & $\begin{array}{c}\text { Area, } \\
\mathbf{\%}\end{array}$ & Direction & $\begin{array}{c}\text { Area, } \\
\mathbf{\%}\end{array}$ \\
\hline Flat & 1.78 & South East & 12.90 \\
North & 12.73 & South & 12.89 \\
North East & 11.47 & South West & 11.65 \\
East & 11.82 & West & 11.85 \\
& & North West & 12.91 \\
\hline
\end{tabular}

d) Sea Level Rise: The study area is one of the most fertile land of Alexandria and El Behira governorates and hosts most of the agricultural productivity. Its shoreline has relatively low elevation areas. In addition the Delta suffers from land subsidence that increases from west to east. Hence it is highly vulnerable to potential impacts of climate change and sea level rise. Map (16) shows that an increase in sea level rise $0.5 \mathrm{~m}$ will submerged an area about $85.73 \%$ of the total area. If the sea level rise increase to $1 \mathrm{~m} 90.73 \%$ of the study area will submerged as shown in map (17). 


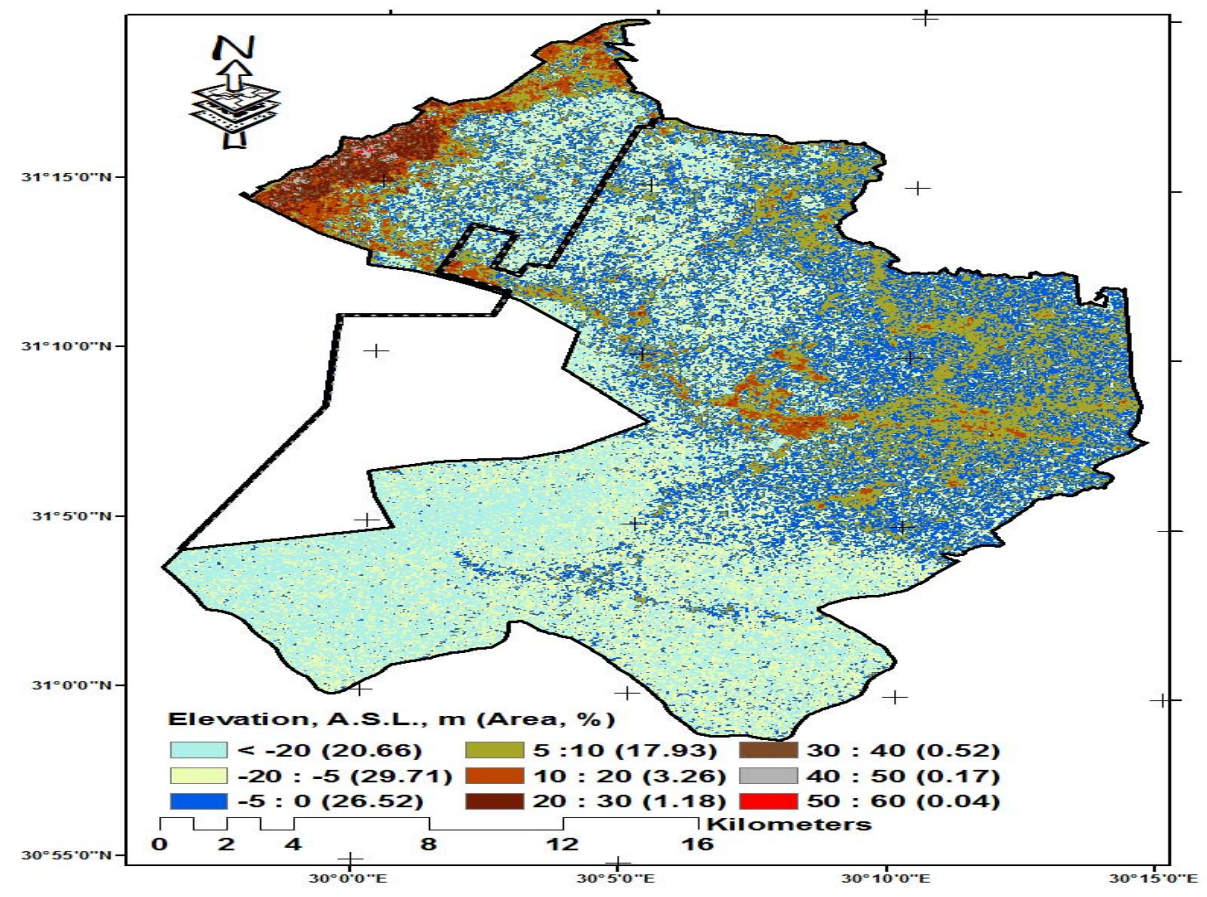

Map 15. Digital Elevation Model (DEM) of the study area

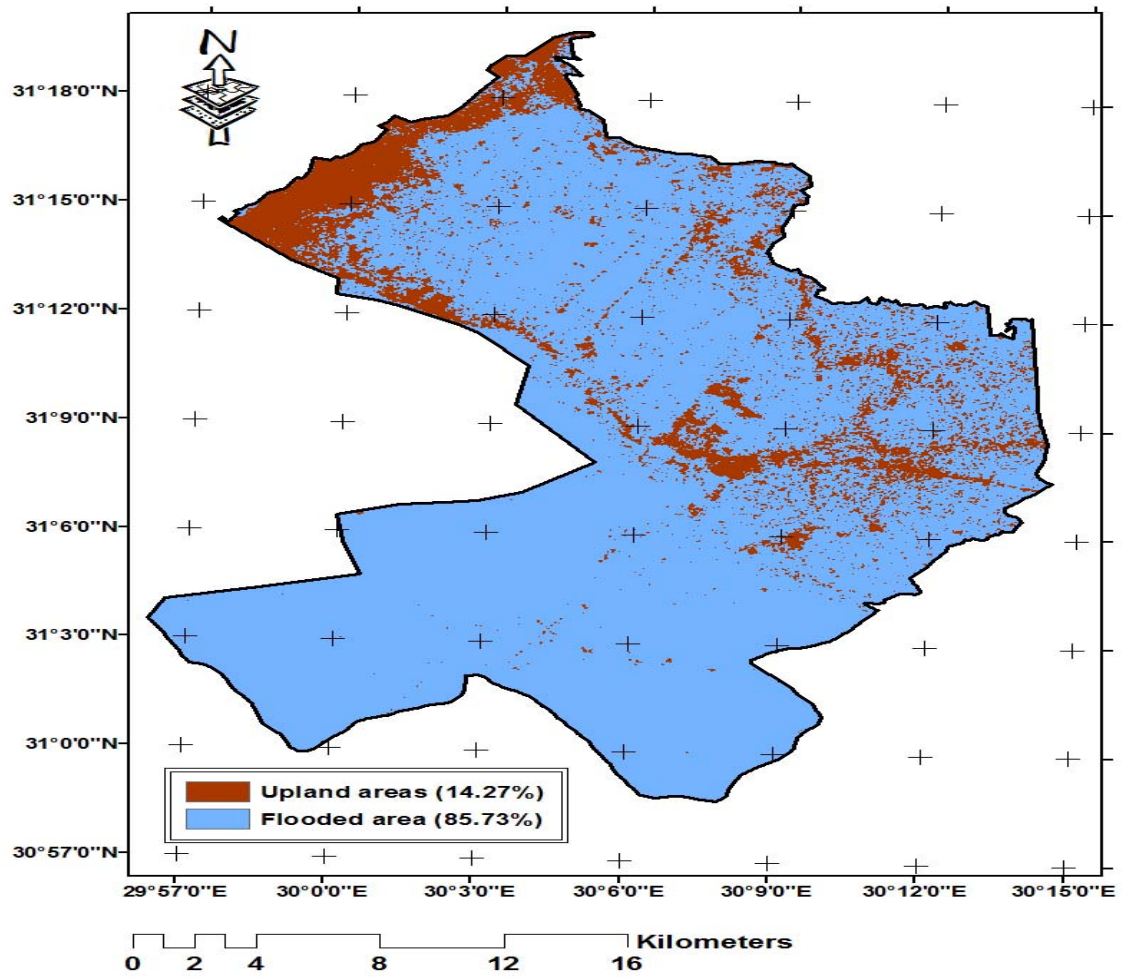

Map 16. Potential impact of sea level rise with a $0.5 \mathrm{~m}$ 


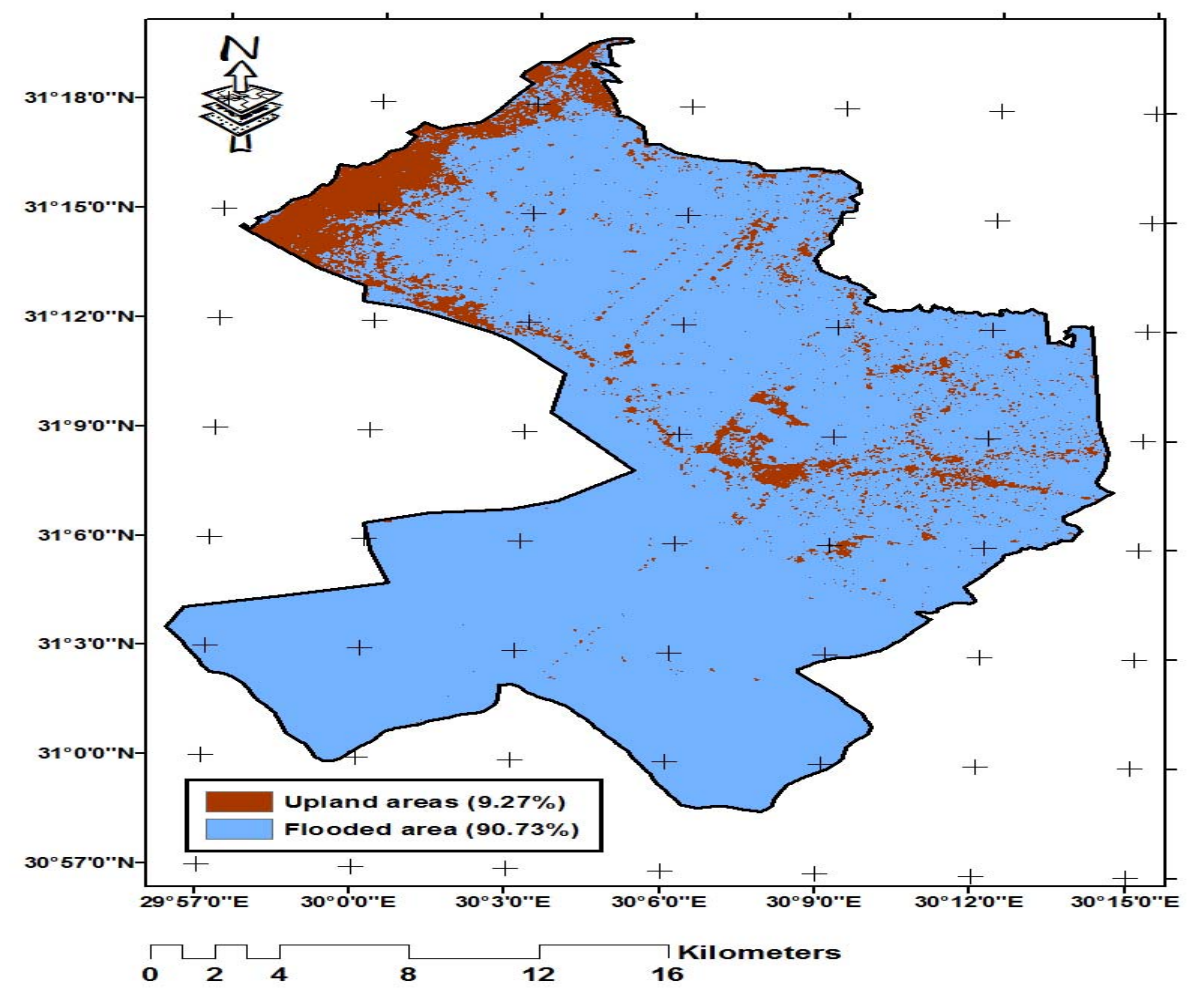

Map 17. Potential impact of sea level raise with a $1 \mathrm{~m}$

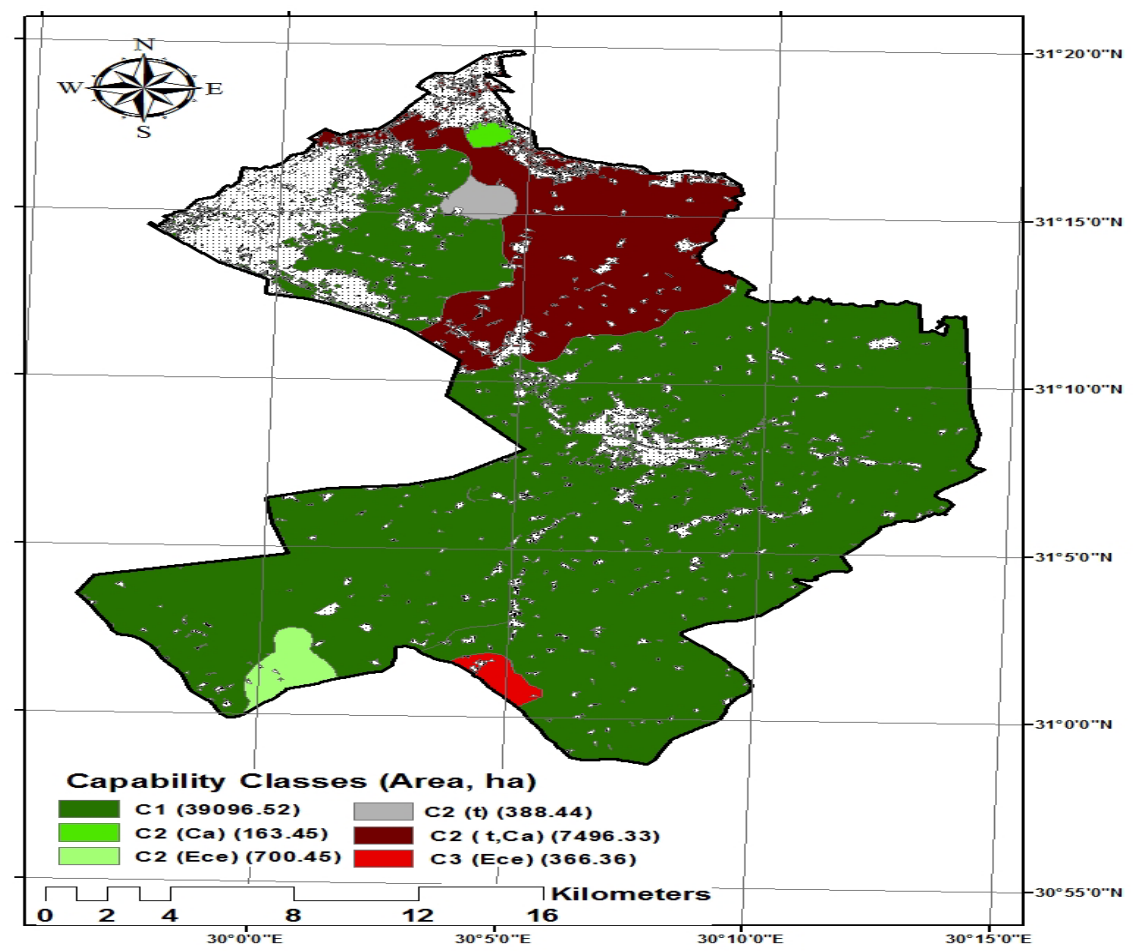

Map 18. Land capability classes of the study area 
To protect this very important coastal region, numerous water defense strategies have been intensified along beaches of Alexandria and the vulnerable delta shores to combat beach erosion. These strategies are mainly technical solutions, including protection works such as inlet lagoon and harbor jetties, groins, seawalls, detached breakwaters, as well as beach nourishment. Mitigation measures, which started as early as 1780 are in progress and others, are planned for the future.

4.1.3. Land evaluation: The ALES Model (Applied Land Evaluation System) provides prediction for general land use capability as well as suitability for a broad series of different crops. According to the model prediction, most of the study area was classified as (C1), which indicated high capability with no limitations, it covered an area about 39096.52 ha. mostly focused in the southern and middle parts of the study area. Data show that $(\mathrm{C} 2 \mathrm{t}$, $\mathrm{Ca}$ ) class which indicated moderately capability with soil texture and calcium carbonate content as limiting factor covered an area about 7496.33 ha. mostly focused in the area in between the two governorate and the area closed to Idko lake, followed by $(\mathrm{C} 2$, Ece) class which indicated moderately capability with soil salinity as limiting factor concentrated as a spot in the south of the study area as shown in map (18).

4.1.4. Land suitability classes for specific uses: The ALES model coupling with GIS was used to predict suitable cropping pattern for some common crops cultivated in the study area including: wheat, maize, alfalfa, cotton, fababean, tomato, potato, pepper, peanut, soyabean, sorgum, onion, rice, tomato, citrus, grape, apple, pear, banana and watermelon. Finally maps $(19,20$ and 21) show the distribution and suggested cultivated crops for each soil units in the study area.

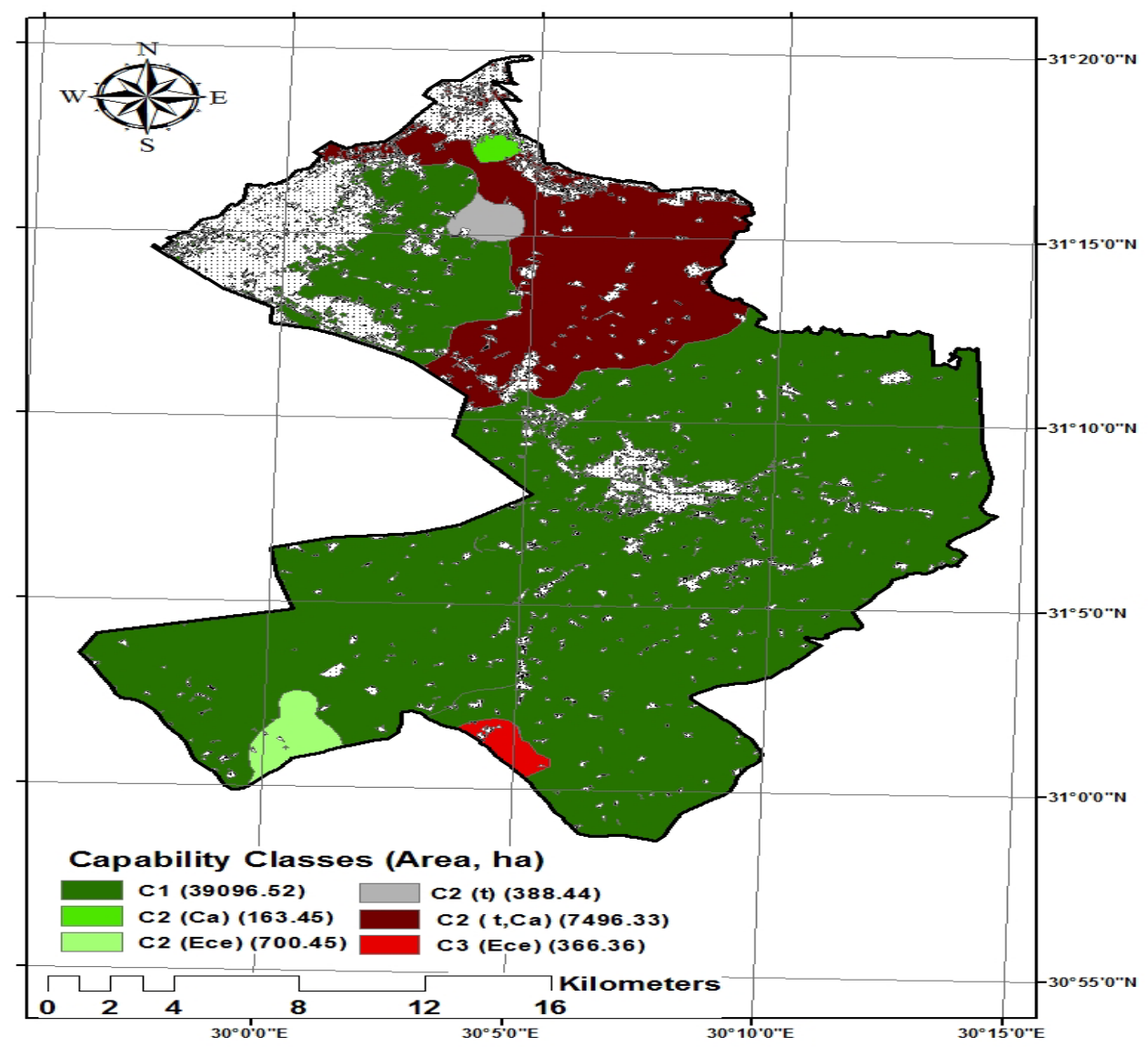

Map 18. Land capability classes of the study area 


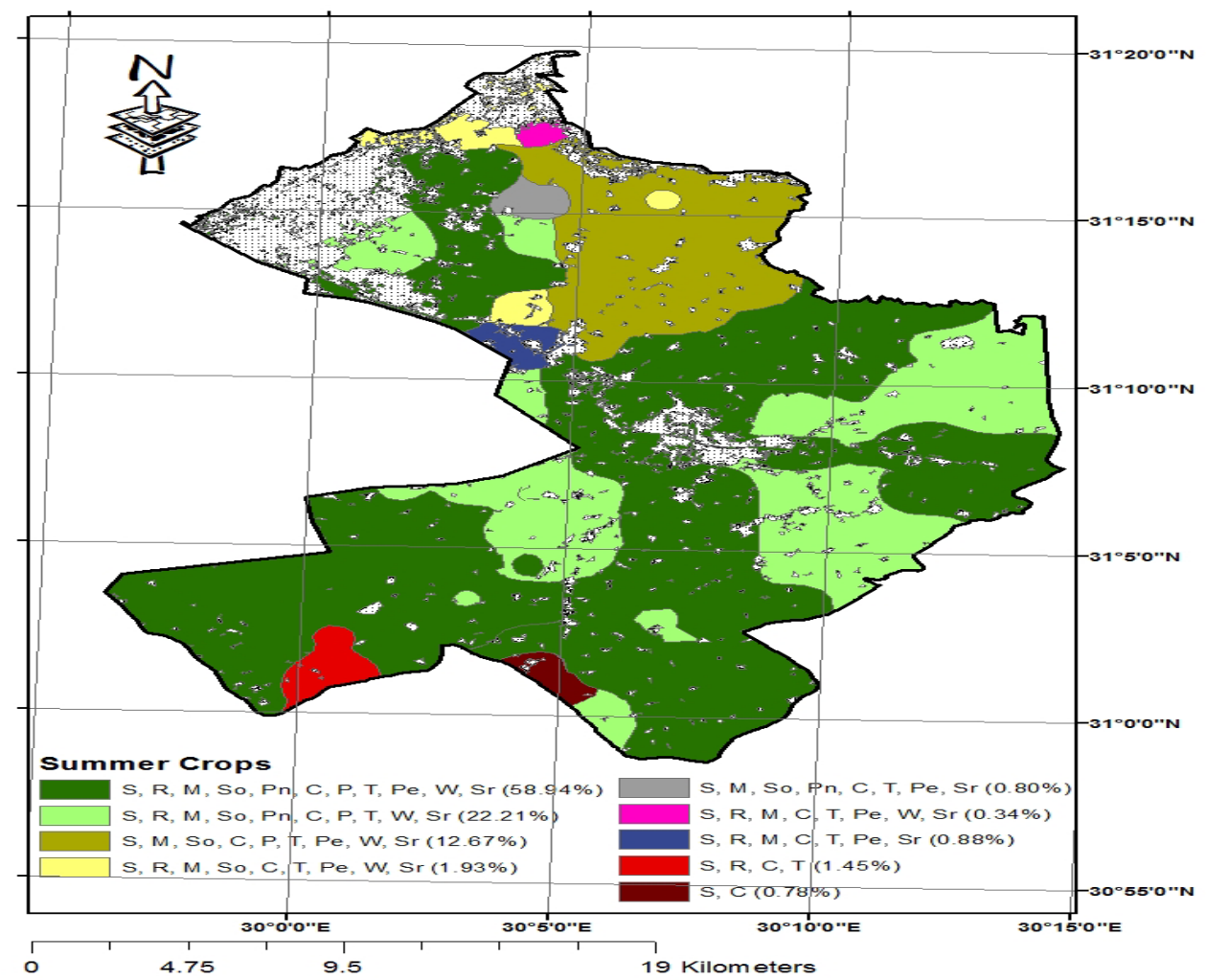

Map 19. Suitability of summer crops in the study area

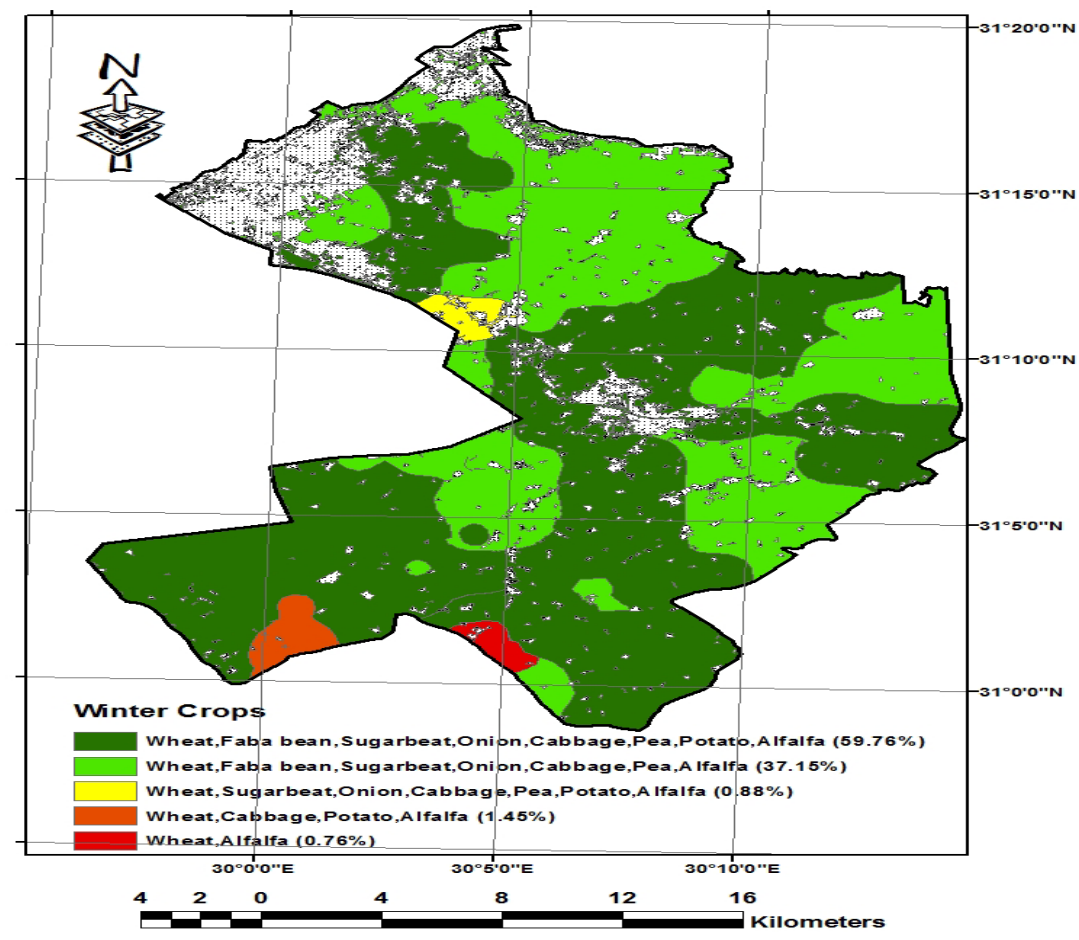

Map 20. Suitability of winter crops in the study area 


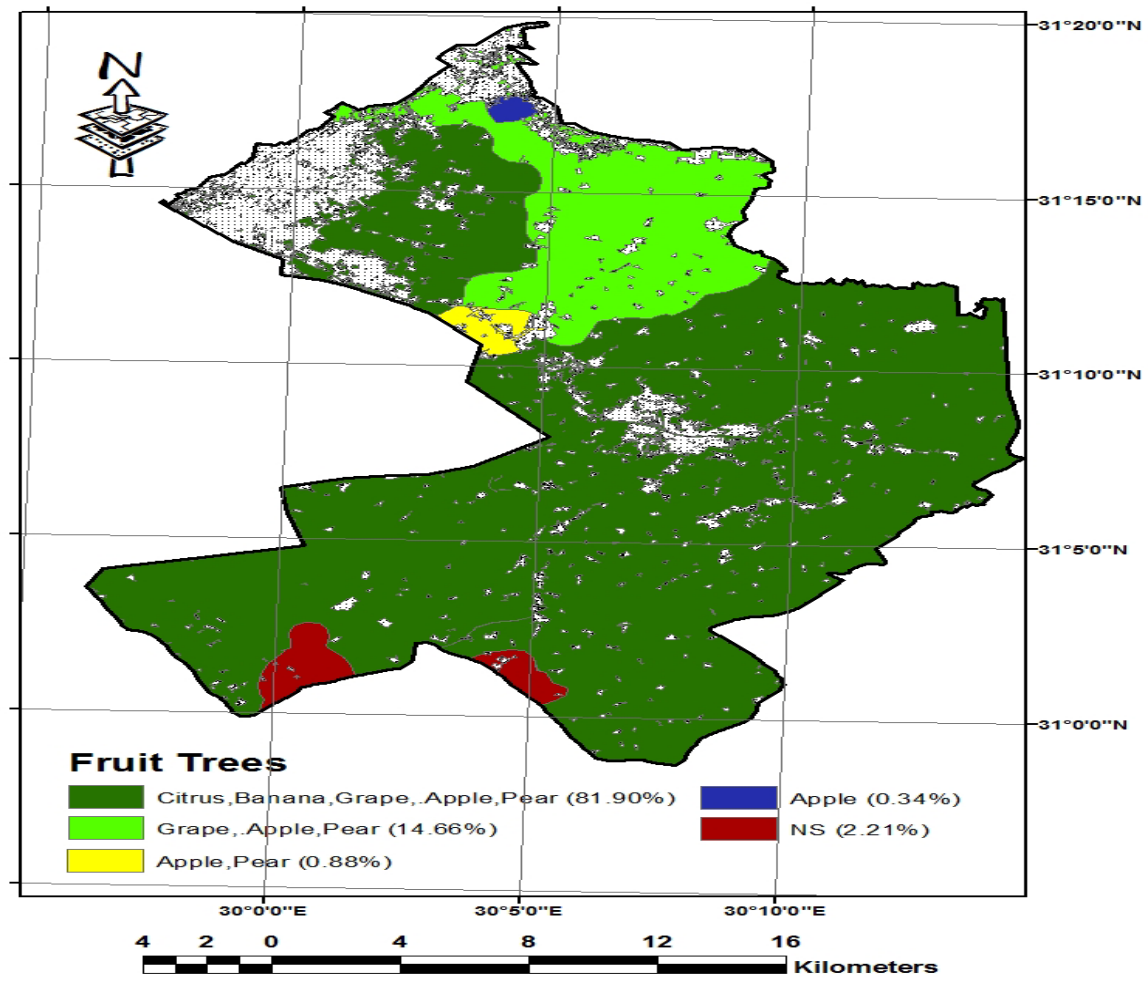

\section{Map 21.Suitability of fruit trees in the study area}

Where: $\quad \mathrm{S}=$ Sunflower, $\mathrm{R}=$ Rice, $\mathrm{M}=$ Maize, So=Soyabean, $\mathrm{Pn}=$ Peanut,$\quad \mathrm{C}=$ Cotton, $\mathrm{P}=$ Potato, $\mathrm{T}=$ Tomato, $\mathrm{Pe}=$ Pepper, $\mathrm{W}=$ Water melon, $\mathrm{Sr}=$ Sorgum

\section{CONCLUSION}

Emerging technologies like high resolution satellite data can be utilized successfully for deriving the spatial and temporal agricultural information at micro level. Organizing the satellite derived spatial data and ground observations and non-spatial attribute data, in a remote sensing, GPS and GIS environment, would be highly desirable to facilitate the sustainable development of the specific region. This research results on land resources management in general and on methodology for thematic maps compilation in particular will serve as scientific basis to workout agricultural development strategy in different stages of national economy development. It will also serve as scientific basis for economy planning, appropriate land use planning for increasing efficiency of agro-forestry production and recommending measures to improve actual land capability to ensure a sustainable land resources development. These results draw attention towards the importance of upgrading awareness of decision-makers and planners to the potential future impacts of sea-level rise on this north coastal areas region of Egypt. However, to be more efficient, this study should include other assessments. In particular, it is recommended that the impact of sea-level rise on freshwater resources, including the saltwater intrusion and water logging problems should be considered; Vulnerability assessments should include detailed socioeconomic impacts, together with evaluation of the costs of these impacts and those of the adaptation measures.

\section{REFERENCES}

Abd El-Kawy O.R., H.A. Ismail, J.K. Rod and A.S. Suliman 2010. A developed GIS-based land evaluation model for agricultural land suitability assessments in arid and semi arid regions. Res. J. of Agric. And Biological Sci. 6 (5): 589-599.

Beek, K. J., K. De Bie, and P.,Driessen, 1997. Land information and land evaluation for land use planning and sustainable land management. Land Chatham, 1997, 1, 27-44.

Cronin, R. 2009. Exploiting natural resources: Growth, instability and conflict in the Middle East and Asia. The Henry L. Stimson Centre. Washington.

Dobos, E.; E.Micheli, Baumgardner, M.F.; L.Biehl, and T. Helt. 2000. Use of combined digital elevation model and satellite radiometric data for regional soil mapping. Geoderma. 97: 367-391.

ENVI, 2008. The Environment for visualizing images, version 4, Colorado, USA.

ERDAS 2008. Geographic imaging Made Simplesm. ERDAS Version 8.50 Inc. Atlanta, Georgia. 
ESRI 2014. Arc-GIS 10.3 spatial analyst. Redlands. CA, USA.

FAO. 2010. Guidelines for soil description. Fourth Edition. Food and Agriculture Organization of the Unoted Nations Rome, 2006.

Foote, K.E., and M.Lynch. 1996. Geographic information systems as an integrating technology: context, concepts and definition. University of Texas, Austin.

Ghafari, A., H.F.Cook, and H.C.Lee. 2000. Integrating climate, soil and crop information: a land suitability study using GIS. In: 4th International Conference on Integrating GIS and Environmental Modeling (GIS/EM4). Problems, Prospects and Research Needs, Banf, Alberta.

Ismail, H. A., I. Morsy, B. A. Zamil, and N. I. Talha. 2011. Land evaluation of old irrigated soils in the Middle of Delta Region. Alex. Sci. Exch. J. 32(2): 225-226.

Klute, A. (ed.). 1986. Methods of soil analysis. Part 1 Physical and mineralogical methods. 2nd ed. SSSA Book Series No. 5. SSSA and ASA, Madison, WI.

Nicholls RJ. and S.P. Leatherman 1995. Global sea-level rise. pp. 92-123. (Strzepek and Smith).

Ocean US, 2007. Global Warming Causing Mediterranean Sea to Rise, Threatening Egypt's Lush Nile Delta. Ocean US, 24 August 2007.

https://orbi.ulg.ac.be/bitstream/2268/168225/1/Egypt\%20Delt a02\%20Final.pdf
Page, A. L., R. H. Miller and D. R. Keeney, 1982. Methods of soil analysis; 2. Chemical and microbiological properties, American Soc. of Agronomy (Publ.), Madison, Wisconsin, USA.

Palacios-Orueta, A.P., and S.L Ustin. 1998. Remote sensing of soil properties in the Santa Monica mountains, spectral analysis. Remote Sens. Environ. 65, 170-183.

SPSS for windows. 2003. Copyright, Version (12), standard license.

Saleh, A.M., A.A.Belal, and S.M. Arafat. 2013. Identification and mapping of some soil types using field spectrometry and spectral mixture analyses: a case study of North Sinai, Egypt. Arabian J. Geosci. 6 (6), 17991806.

Saleh, A.M., and A.A.Belal. 2014. Delineation of site-specific management zones by fuzzy clustering of soil and topographic attributes: a case study of East Nile Delta, Egypt. In: 8th International Symposium of the Digital Earth (ISDE8). IOP Conf. Series: Earth and Environmental Science 18 (2014) 012046. IOP Publishing.

World Food Programme, 2013. The Status of Poverty and Food Security in Egypt: Analysis and Policy Recommendations. World Food Programme.

World Health Organization, 1996. The world health report 1996 - Fighting disease, fostering development. http://www.who.int/whr/1996/en/ 


\section{المالضص العري}

\section{لمتخدلم ظام المعلومل الجغراليه وقنيلت الستشعار عن بعدف فقيم الموارد الالبيعيه والثار الرفاع

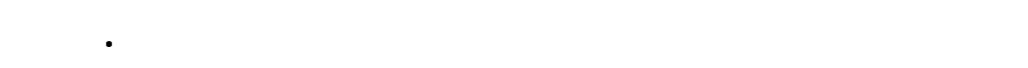

\author{
محمد لسماعل، هيثم عبد الطيف يحيى، اليهلب محرم محمد مرسى
}

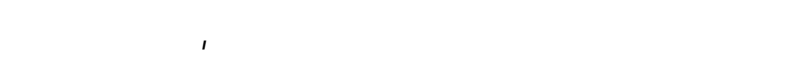
وتتضمن مظقه الدرلسه مركز كفر الدوار وهو من لكبر المنار

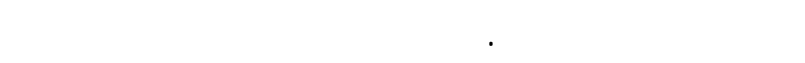

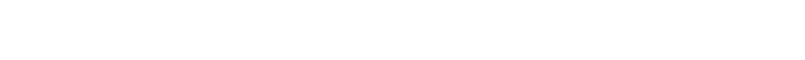
قنوات الرى وكذلك المصارف والماء الارض للتعرف على خواص الموارد المائيه لمطقه الدرلسه. قم درلسه

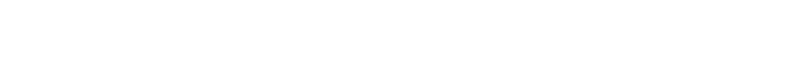

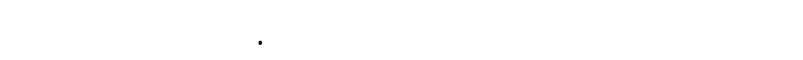

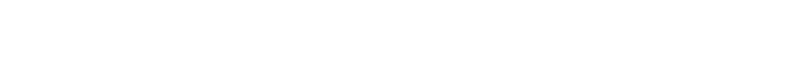

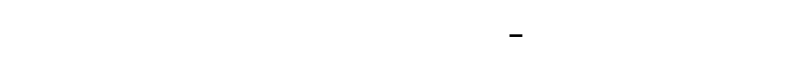
مستوى سطح البحر وان ارقفاع مستوى سطح البحر اله له

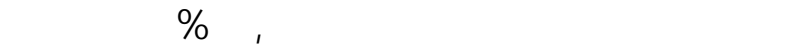
الدرلسه.
ان لستخلاص المعلومات فى الوقت المنلبب عنطبيعيه التربه وخواصها وتوزيعها الفراغى ى يعتبر المر بالغ الغ الغئ الاهميه لاستغلال هذه الموارد الطبيعيه المتلحه فى التميه الزراعيه المستدامه. القهم التكنولوجي في مجل نقنيت

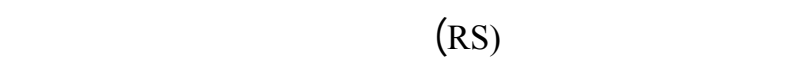
وقام المعلوملت الجغرافيا (GIS) (GIS) اعطى كفاء ودقه (RS)

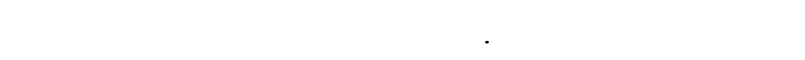
اظمه الحلبب الاله المقدمه وقاعه بيانات الموارد

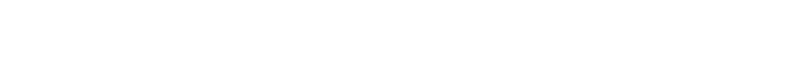
خطط التنميه الزراعيه المستدلمه المسقبليه لهذه الموراد دون الاضرار بالظلم البيئ. مطقه الدرلسه تغطى مسلحه

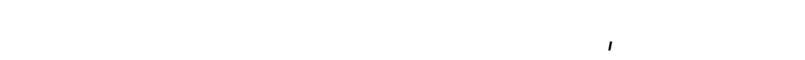

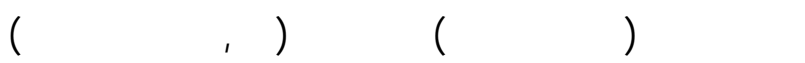

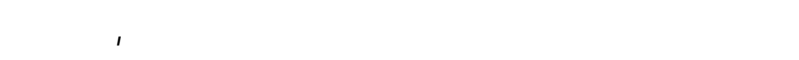

